\title{
Validation of the COVID-19 Transmission Misinformation Scale and Conditional Indirect Negative Effects on Wearing a Mask in Public
}

\author{
Stephen Bok ${ }^{1, * \mathbb{D}}$, Daniel E. Martin ${ }^{2}$, Erik Acosta ${ }^{1}$, Maria Lee ${ }^{3}$ and James Shum ${ }^{4}$ \\ 1 Marketing Department, California State University, 25800 Carlos Bee Blvd, Hayward, CA 94542, USA; \\ eacosta10@horizon.csueastbay.edu \\ 2 Management Department, California State University, 25800 Carlos Bee Blvd, Hayward, CA 94542, USA; \\ daniel.martin@csueastbay.edu \\ 3 Department of Urban Planning and Public Policy, University of California, Berkeley, CA 92697, USA; \\ maria.lee@me.com \\ 4 Accounting Department, Loyola Marymount University, Los Angeles, CA 90045, USA; jjshum14@gmail.com \\ * Correspondence: stephen.bok@csueastbay.edu
}

Citation: Bok, S.; Martin, D.E.; Acosta, E.; Lee, M.; Shum, J. Validation of the COVID-19 Transmission Misinformation Scale and Conditional Indirect Negative Effects on Wearing a Mask in Public. Int. J. Environ. Res. Public Health 2021, 18, 11319. https://doi.org/10.3390/ ijerph182111319

\section{Academic Editors:}

Sarah Moreland-Russell, Shelley Golden and Allison Myers

Received: 24 August 2021

Accepted: 19 October 2021

Published: 28 October 2021

Publisher's Note: MDPI stays neutral with regard to jurisdictional claims in published maps and institutional affiliations.

Copyright: (c) 2021 by the authors. Licensee MDPI, Basel, Switzerland. This article is an open access article distributed under the terms and conditions of the Creative Commons Attribution (CC BY) license (https:// creativecommons.org/licenses/by/ $4.0 /)$.

\begin{abstract}
The SARS-CoV-2 (COVID-19) pandemic devastated the world economy. Global infections and deaths altered the behaviors of generations. The Internet acted as an incredible vehicle for communication but was also a source of unfounded rumors. Unfortunately, this freedom of information sharing and fear of COVID-19 fostered unfounded claims about transmission (e.g., 5G networks spread the disease). With negligible enforcement to stop the spread of rumors and government officials spouting unfounded claims, falsities became ubiquitous. Organizations, public health officials, researchers, and businesses spent limited resources addressing rumors instead of implementing policies to overcome challenges (e.g., speaking to defiant mask wearers versus safe reopening actions). The researchers defined COVID-19 transmission misinformation as false beliefs about the spread and prevention of contracting the disease. Design and validation of the 12-item COVID-19 Transmission Misinformation Scale (CTMS) provides a measure to identify transmission misinformation believers. Indirect COVID-19 transmission misinformation beliefs with a fear of COVID-19 decreased wearing a mask in public intentions. Callousness exacerbated COVID-19 transmission misinformation beliefs as a moderator.
\end{abstract}

Keywords: COVID-19 Transmission Misinformation Scale (CTMS); validation; reliability; interitem correlation; predictive validity; moderated mediation analysis

\section{Introduction}

Preventative measures such as mask wearing and physical distancing have reduced the spread of COVID-19 and saved lives [1-3]. Unfortunately, politicians [4] and social media speculation [5] spread falsities that reduced cooperation during the early stages of the COVID-19 pandemic in the U.S.A. COVID-19 rumors rampantly spread online and became commonplace on social media newsfeeds [6]. For example, natural homeopathies (e.g., garlic) were propagated as a means to increase someone's natural immunity to prevent contraction [7]. However, no scientific evidence has proven natural homeopathies such as garlic prevents COVID-19 infections. Belief in COVID-19 rumors reached across segments throughout society [8]. Similar to how COVID-19 did not selectively infect persons for a single predisposition, misinformation spread across society and was picked up across different groups of people. This abstract phenomenon illustrated that a psychological construct was warranted to capture this collective misunderstanding of COVID-19 transmission.

There was a misbelief that COVID-19 was just like the flu and people would receive care if they became ill [7]. Hospitals without the space and resources triaged the likelihood of survival before admitting severe cases $[9,10]$. The outbreak in New York City in 2020 
overloaded hospitals and the likelihood of mortality was reviewed to develop triage procedures [11]. In some locations, cancer patients received a second level of triage because of limited resources and likelihood to develop severe complications [12]. COVID-19 was real. Transmission did not discriminate between ethnicities and ages [13]. One less patient in the hospital was one more open bed to someone who involuntarily contracted the disease. Misinformation endangered the public, especially when transmission was not visible and symptoms matched other common illnesses.

Months into the COVID-19 pandemic, online forums and communities reinforced false claims that researchers spent valuable time debunking [14]. COVID-19 transmission misinformation required U.S. public health organizations to create educational campaigns and webpages to counter this $[15,16]$. As COVID-19 shared similar symptoms to the common flu (e.g., cough and fever), perceived existence depended on trust and belief in health sciences [17]. Many contracted COVID-19 but did not develop symptoms, which further obfuscated societal acceptance $[18,19]$. It was projected that over $50 \%$ of new cases in 2020 were transmitted by asymptomatic COVID-19 carriers [20]. The abstract and invisible nature of the disease made transmission rumors likely to spread [21].

Social influencers shaped societal misconceptions about COVID-19 [7]. For example, in the U.S.A., politicians emphasized that COVID-19 originated in China and claimed COVID19 was a foreign government conspiracy [22,23]. This distraction stoked racial tensions and the false belief that COVID-19 could only infect those with less civilized cleaning practices [8]. However, COVID-19 did not discriminate based on ethnicity or age [24]. This rhetoric was found to be associated with lower perceived COVID-19 threat [25]. COVID-19 conspiratorial beliefs associated with less cooperation to safety guidelines [26]. By not participating in proven safety measures, such as wearing a mask, many people unnecessarily contracted the disease. This study created the CTMS with predictive validity results on likelihood to wear a mask to demonstrate utility.

The existence of COVID-19 transmission falsehoods hindered the work of public health organizations to perform essential health related duties [27]. Debunking misinformation cost health care resources and time. For example, scientists debunked the unsupported claim that cold weather would kill the virus and it would go away [28]. Counter to this claim, COVID-19 cases increased with lower temperatures. The claim disregarded humans as warm body carriers more susceptible to diseases in lower temperatures (i.e., a basic premise of human infectious diseases). With more cases, the health care industry became overburdened with fewer resources (e.g., ventilators) to treat severe cases [29-32]. Medical and nursing students were granted accelerated courses to help overstrained facilities in Denmark [33]. Misinformation contributed to active (e.g., COVID-19 parties) and passive (e.g., live life as if there is no pandemic) contagion. A greater number of infections utilized limited health care resources to treat cases [34]. Increasing cooperation to participate in scientifically proven safety measures was a challenge for health officials during the pandemic. Therefore, the COVID-19 Transmission Misinformation Scale (CTMS) was created to encompass major transmission falsehoods perpetuated to study misinformation believers. With the CTMS, we analyzed the relationship of COVID-19 fear and callousness to access antecedents to wearing a mask in public despite holding false beliefs.

\subsection{Theory of Rumor Dissemination}

Rumors were theorized as the communication of subjective information not based on truth to explain occurrences within personal and cultural contexts [35]. Allport and Postman (1945) postulated that the degree of ambiguity and importance corresponded to the pervasiveness of rumors spreading. For instance, in the aftermath of the Pearl Harbor attacks, society was inundated with rumors [36]. In circumstances of uncertainty and anxiety, individuals try to make sense of events [37]. In these gullible times when logical facts are lacking, rumors appear believable [38,39]. "Moral panics" (i.e., travesties or perceived evildoers causing societal harm) generate a desire to share information to help [40,41]. For instance, fear for the safety of others during the initial outbreak of 
COVID-19 increased sharing of concocted stories of COVID-19 misinformation [42,43]. Latin doctors and hospitals were not kidnapping elderly patients for financial profits under the guise of COVID-19 infections [44]. Drinking more water does not stimulate stomach acids that kill the COVID-19 virus [45]. Rumors have pervaded overtime to fill a lack of factual data [46].

Rumors can be true or false. Rumors are part of public discourse that have historically aided in remembering information [47]. For example, stories of a berry sickening a traveler can save others from repeated illness. Fine (2007 p. 8) states, "rumors depend on other beliefs, texts and narratives for an assessment of their credibility". Contemporary rumors reinforced by communities, forums, and multiple sources establish a culture and collective misunderstanding. When wielded for political gains, rumors can distract the public and cast doubt on existing institutions to mobilize citizens through fear [48]. For example, U.S. political claims of "fake news" were used to discredit mainstream media outlets [48]. Over time, this has created U.S. societies with lower trust and confidence in public institutions, which was found to be associated with greater belief in rumors [14]. Excessive information and suspicion in government has fostered an environment wherein citizens are more likely to believe COVID-19 transmission falsehoods.

Rumor dissemination has expanded from oral to nonoral communication [49]. The context, style, exterior shape, content, and method of propagation can affect society's uptake [50]. Social networking platforms provided a vehicle for instantaneous hearsay diffusion through established trusted connections [51]. Epistemic naïve participants were more likely to share medical misinformation online [52]. Personal involvement, in a study on cancer rumors, increased intentions to trust and share misinformation among a medically knowledgeable experimental group [53]. Social media behaviors such as sharing and commenting are personal involvement activities. For example, participation in the Twitter post \#filmyourhospital increased personal involvement, building faulty COVID-19 evidence that the pandemic was not real because hospitals were not visibly overflowing with patients [54,55]. COVID-19 rumors pose an ongoing risk to public health aggrandized by the abstract nature of epidemiology and rapid dissemination of misinformation online.

Sensationalized news instantaneously spreads in the social media marketplace because ideas compete for users' attention [51]. There are financial incentives for click-bait-worthy news. There are social benefits to sharing misinformation (e.g., Twitter attention in the form of likes and comments). This is particularly harmful in the health field when misinformation interrupts lifesaving preventive care [56,57]. COVID-19 misinformation proliferated in society by unregulated internet websites and social media platforms. Social media fostered an online environment for transmission misbelief to permeate throughout society and communities to rapidly reinforce misunderstanding.

Falsehoods on COVID-19 transmission clouded uniformity in societal practices to combat the spread of the disease. For instance, if someone falsely believed that the mechanism of COVID-19 transmission is not through respiratory droplets spread through the air, they incorrectly reasoned face coverings would not prevent contraction. Fortunately, with advanced technology, scientists quickly studied COVID-19 transmission [34,58]. While COVID-19 misinformation became ubiquitous and took hold in society during the initial outbreak, new transmission claims did not [45]. COVID-19 transmission rumors remained constant as respiratory airborne spread was confirmed by researchers as a major source of transmission [59]. The ongoing COVID-19 pandemic warranted the development of the CTMS. Researchers need tools to study individuals prone to misinformation and additional methods to combat counterproductive misinformation dissemination.

\subsection{Persistence of Rumors in Society despite Evidence-Based Facts}

Despite counterevidence to disprove misinformation, rumors can persist in society [60]. Cultural acceptance, and socialization of ideas can enable rumors to last over time [61]. For example, discovered facts disseminated about HIV transmission had difficulty dispelling misunderstandings about contraction through the "casual contact" and "shelf life" of the 
virus [62]. Goldstein (2004) described the "rise of the educated lay person and the bloating of medical authority" (p. 171). A saturation of varying online information can produce resistance to medical professionals and public health policies. Regardless of personal beliefs or motives, rumors spread through interpersonal communication.

The medical community educates the public about disease prevention, benefits of treatments, and how treatments work. Unfortunately, the existence of alternative health websites with unproven statements [63], inaccurate disease transmission information [64], and vaccination folklores [65] poses public health problems that are not properly addressed. For instance, Kitta and Goldberg (2017) explained that the lack of evidence-based medical information was not the core reason people choose not to be vaccinated, but the false narratives that promote anti-vaccination behaviors. Accurate information is readily available, but there are individuals that choose to seek out and believe unproven statements online $[66,67]$. For example, Briggs and Hallin (2016, p. 45) described a news story framing the government as slow to respond and investigators failing in their oversight. The surfeit of public health news coverage casts doubts on what to believe [68]. This creates an environment with contradicting stories and skepticism opposing official public health messaging.

Hence, COVID-19 transmission misinformation belief was defined as those that believed falsities about how the disease was spread and prevented, not vetted as true by the scientific and public health community. For example, there was no scientific support that house flies transmit COVID-19. This rumor was fabricated but spread online through social media.

\subsection{Fear of COVID-19 and Behavioral Changes}

The gravity of the COVID-19 pandemic shut down the global economy and international travel [69]. World leaders and celebrities contracted the disease [7]. News outlets reported daily infection and deaths [70]. Travesty touched the lives of millions around the world as loved ones received news of contraction or job losses. The fear of COVID-19 gripped society as health officials emphasized the risks of in-person social interactions [71]. Fear elicited cooperation to shelter-in-place and wearing masks in public for personal safety in the U.S.A. [72]. Internationally, the perceived risk of COVID-19 infection related to greater mask wearing in public among a German [73] and Vietnamese sample [74]. The fear of COVID-19 stimulated behavioral changes. Figure 1 illustrates the hypothesized relationship examined for predictive validity.

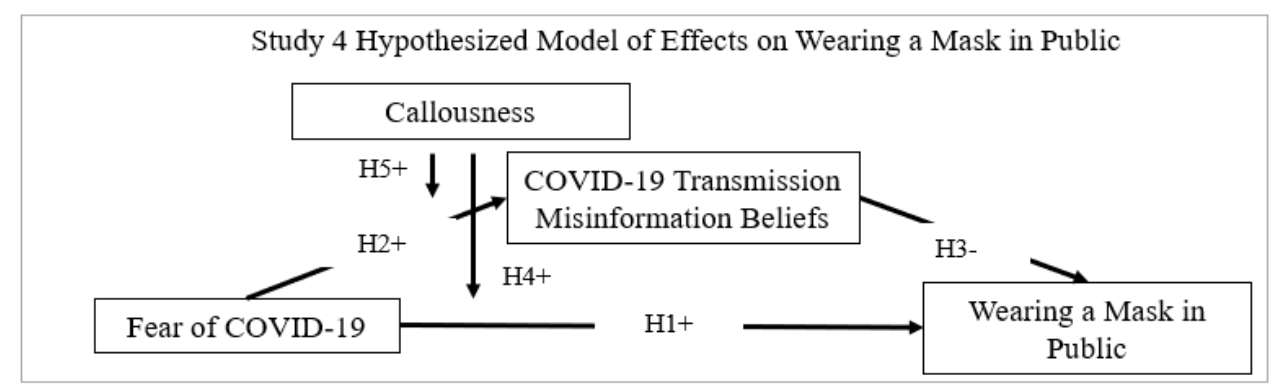

Figure 1. Study 4 hypothesized model of effect on wearing a mask in public.

Hypothesis 1 (H1). Higher fear of COVID-19 will relate to greater mask wearing intentions in public.

\subsection{COVID-19 Transmission Misinformation}

Scientists identified COVID-19 transmission primarily occurring through respiratory air droplets and touching one's face after touching a surface with the virus [20,21,75]. Misinformation was present on social media and news circuits before scientists could study 
the disease transmission properly in controlled settings. A problem with misinformation is difficulty unseeing misinformation [76,77]. It becomes part of someone's thought process and judgement about an issue even when facts are presented afterwards [78]. Rumors seized hold in society regardless of whether accurate information successfully adjusted preconceived misinformation.

Thereby, public awareness of COVID-19 transmission inaccuracies remained omnipresent [45]. Despite widely available facts and debunking campaigns, misinformation believers maintained their false beliefs months later into the COVID-19 pandemic. This provided the opportunity to create the CTMS because the circulation of rumors and facts stabilized. Given COVID-19 continued to be an ongoing danger to public health, the CTMS offered a tool to identify and reach misinformation believers.

During the initial outbreak of COVID-19, more pandemic-related content was generated [17]. The public also consumed more pandemic-related media [79]. Increased social media discourse fostered an environment of fear because of unvetted information [80]. Researchers described this as an infodemic that coincided with the initial outbreak of COVID-19 [79]. Due to this uncertainty and heightened fear, it was hypothesized that fear of COVID-19 increased the consumption of misinformation.

Hypothesis 2 (H2). Higher fear of COVID-19 will relate to greater COVID-19 transmission misinformation beliefs.

Facial covering in public was a main recommended public health guideline to combat COVID-19 contagion [15]. Unfortunately, hearsay (such as consuming certain foods, including garlic, liquor, and pepper) permeated as means of protection. Greater belief in these rumors was expected to create a false sense of protection and reduce participation in the evidenced-based practice of mask wearing.

Hypothesis 3 (H3). Higher COVID-19 transmission misinformation beliefs will relate to reduced mask wearing intentions in public.

\subsection{Callousness and Social Interactions}

Callousness is a lack of emotional sensitivity and understanding of others [81-83]. This construct related to unfavorable romantic relationship outcomes (e.g., relationship dissatisfaction and relationship violence) [84], youth aggression [85], and psychopathic qualities with juvenile offenders $[81,86]$. Callousness related to lower amygdala responses to fearful expression stimuli among adolescents [87]. Disconnect from the impact of personal behaviors on others implies that callousness relates to concern for oneself first over others. Hence, greater fear of COVID-19 and callousness was postulated to increase wearing a mask in public for personal protection.

Hypothesis 4 (H4). Callousness will moderate the relationship between fear of COVID-19 beliefs and wearing a mask in public. Higher levels of callousness and fear of COVID-19 will relate to higher mask wearing intentions in public.

Misinformation was omnipresent during the initial COVID-19 outbreak. Accurate transmission information was second when scientific studies published findings. Callousness is a lack of emotional concern and response to others [88]. In fact, mask wearing in the U.S.A. was hotly debated as a preventative measure [89]. Health websites emphasized wearing a mask to protect others (not necessarily oneself). Such messaging muddled how someone could prevent contraction. Many COVID-19 transmission inaccuracies appeared plausible at face value (e.g., COVID-19 will go away with cold weather). Meanwhile, facts such as that COVID-19 is spread person-to-person (often from asymptomatic carriers) can be difficult to comprehend for those lacking reflective skills. Others are a source of a correcting misunderstanding. For example, someone sharing how their father contracted 
COVID-19 singing at a karaoke bar and dying from serious complications may not resonate with someone stiff in their beliefs about COVID-19. A callous response may be "How does this personally affect me?". Hence, the researchers postulated that reeducating individuals with greater callousness was more difficult, and they were therefore more likely to believe debunked COVID-19 transmission misinformation.

Hypothesis 5 (H5). Callousness will moderate the relationship between fear of COVID-19 beliefs and transmission misinformation beliefs. Greater callousness and fear of COVID-19 will relate to greater COVID-19 transmission misinformation beliefs.

\subsection{Overview of Studies}

Psychometric theory is the foundation of instrument development for research [90,91]. The design and creation of the CTMS has several benefits to the health care industry. It lists common falsehoods for a short economical measure as a tool for identifying misinformation believers and strength of beliefs. This provides researchers with a tool for ongoing investigation of this construct.

Studies one through four followed standard practices for developing new construct measures $[92,93]$. Factor analysis, descriptive statistics, and consensus of misinformation beliefs were assessed across all four studies.

Studies 1 through 3 assessed multiple samples and measures for uniqueness as a new construct. These studies performed reliability, convergent validity, and discriminant validity analysis.

Study 4 conducted similar analyses as the previous studies. In addition, study 4 extended results by also collecting dependent variable data (i.e., wearing a mask in public) to evaluate predictive validity using moderated mediation analysis. Predictive validity advances utility of the measure for future research.

\section{Method}

\subsection{Overview of Studies}

To establish consistency and validity of the CTMS, the researchers conducted four studies with online participants using the survey platform Qualtrics. Four studies allowed for the collection of a wide variety of variables to analyze the convergent, discriminant, and predictivity validity otherwise too long for one study (i.e., cause fatigue and potential surveying error) [94,95].

Recruitment was through the Amazon Mechanical Turk (MTurk) system. Qualified participants viewed standard postings and registered by choice. Participants could only participate in one of the four studies. Amazon Mechanical Turk participants represented all states in the U.S.A. Participants had HIT approval rates of over 97\%, which was found to relate to greater accuracy to attention checks and data quality (recommended over 95\%) [96]. Surveys were completed nationally by U.S. samples during January and February of 2021 over two-week periods. A wide range of multidisciplinary MTurk studies have been conducted and recognized as suitable for generalizable sampling [97]. Psychometric development followed standard scale development processes [92,98,99]. Phase 1 constructed and refined measure items. Phase 2 analyzed the reliability, convergent validity, and discriminate validity. Phase 3 assessed the predictive validity (study 4).

All studies collected responses to the initial 28 items to collate large datasets for varying psychometric analyses. After completing consent, participants completed the full list of CTMS statements, battery of individual difference measures, and demographic questions. Study 4 additionally collected intent on wearing a mask in public for predictive validity analysis. Each of the studies collected different variables to evaluate discriminant and convergent validity with a variety of validated scales. 


\subsection{Phase 1 Initial Item Generation}

The researchers generated the initial list of items for the psychometric design by reviewing the widely held COVID-19 transmission falsehoods $[7,100]$ and reputable public health webpages debunking rumors [16,75]. Well-known falsehoods spread during the first outbreak when it was not clear how the disease was transmitted. Conspiracy-prone social media users spread speculatory COVID-19 transmission inaccuracies that lacked fact-based evidence [5]. The researchers carefully worded each statement to succinctly express one misconception [93]. A rigorous vetting process was performed to assess if the statements fit the criteria for COVID-19 transmission misinformation beliefs. Only those that were considered COVID-19 transmission misinformation related remained in the initial 28-item list.

All survey participants across the four studies rated COVID-19 transmission misinformation statements on a 5-point scale (1-definitely false, 2-probably false, 3-not sure/cannot decide, 4-probably true, 5-definitely true). This followed the same scale points and coding of the Generic Conspiracy Belief Scale, which distinguished between facts and fiction [101]. Each item was randomly presented within the section to minimize ordering bias. Schmidt et al. (2003) and Donnellan et al. (2006) studied the reliability of long forms of measures with short forms. These researchers found short forms of measures to have overall similar reliability scores for the same construct, designed to adequately measure the construct while reducing problems with lengthy surveys [94,95]. In continuous true/false scales, those that slightly believe as true and above are considered believers [101,102]. Most agreeing on statements is ideal for these new objective scales [102].

\subsection{Participant Inclusion}

Completion of the survey and attention checks determined inclusion. Of 2513 total participants over the four studies to attempt the survey, 51 did not complete the survey and 29 failed the attention checks. A total of 2433 online participants remained. For scale development studies, samples over 300 participants are "generally sufficient in most cases" [99]. An estimated 385 or more participants was needed for a confidence level of $95 \%$ with a real value within $\pm 5 \%$ of the measured value for a generally large population. Each study exceeded the suggested and estimated sample size.

\subsection{Inter-Item Correlations and Reduction}

Across the four studies, evaluation of the 28 items for inter-item correlations were acceptable for 15 items. Exclusion of 13 items was based on low inter-item correlations $(|\mathrm{r}| \mathrm{s}<0.30)$ [103]. Items with scores lower than this threshold were removed from the initial list following guidelines for item reduction in scale development [99]. For example, despite the politically popularized misconception that "Facemasks are useless to prevent COVID-19 infection", this item was low on the inter-item correlation threshold. Items displaying values below 0.30 were removed at this time using objective and statistical results to refine the list. Kaiser-Meyer-Olkin (KMO) results showed satisfactory sampling adequacy (see Table 1). Results of Bartlett's test of sphericity indicated items were suitable for factor analysis.

Table 1. Sampling adequacy statistics.

\begin{tabular}{|c|c|c|c|c|c|c|c|c|}
\hline & Study 1 & & Study 2 & & Study 3 & & Study 4 & \\
\hline $\begin{array}{l}\text { Kaiser-Meyer-Olkin Measure of } \\
\text { Sampling Adequacy }\end{array}$ & 0.974 & & 0.970 & & 0.971 & & 0.973 & \\
\hline Bartlett's Test of Sphericity & $\chi^{2}(66)=6889.146$ & $* * *$ & $\chi^{2}(66)=7019.133$ & $* * *$ & $\chi^{2}(66)=6270.147$ & $* * *$ & $\chi^{2}(66)=7460.664$ & $* * *$ \\
\hline
\end{tabular}




\subsection{Factor Loadings}

Parallel analysis and evaluation of the scree plot showed items adequate as one factor. The first item explained $71.95 \%$ of the common variance. Two principal component factor loadings (direct oblimin rotated) analysis produced scores beneath 0.20 for the second factor. Analysis of items forced into two factors provided inadequate scores $[90,104]$. The researchers assessed the new measure appropriate as one factor.

Factor loadings are recommended to have scores above the 0.40 minimum $[105,106]$. More conservative factor loadings top $0.70[107,108]$. Twelve items topped 0.70 factor loading scores. Table 2 illustrates the component scores of the 12-item CTMS retained for deeper analysis.

Table 2. Item-factor loadings and item-level descriptive statistics for COVID-19 transmission misinformation scale (CTMS).

\begin{tabular}{|c|c|c|c|c|c|c|c|c|c|c|c|c|c|}
\hline \multirow{3}{*}{\multicolumn{2}{|c|}{ Item }} & \multirow{2}{*}{\multicolumn{3}{|c|}{$\begin{array}{c}\text { Study } 1(N=597) \\
\text { Alpha }=0.964\end{array}$}} & \multirow{2}{*}{\multicolumn{3}{|c|}{$\begin{array}{c}\text { Study } 2(N=651) \\
\text { Alpha }=0.959\end{array}$}} & \multirow{2}{*}{\multicolumn{3}{|c|}{$\begin{array}{c}\text { Study } 3(N=583) \\
\text { Alpha }=0.960\end{array}$}} & \multirow{2}{*}{\multicolumn{3}{|c|}{$\begin{array}{c}\text { Study } 4(N=602) \\
\text { Alpha }=0.965\end{array}$}} \\
\hline & & & & & & & & & & & & & \\
\hline & & $\mathbf{M}$ & (SD) & $\begin{array}{l}\text { Factor } \\
\text { Loading }\end{array}$ & & & $\begin{array}{l}\text { Factor } \\
\text { Loading }\end{array}$ & $\mathbf{M}$ & (SD) & $\begin{array}{l}\text { Factor } \\
\text { Loading }\end{array}$ & & (SD) & $\begin{array}{l}\text { Factor } \\
\text { Loading }\end{array}$ \\
\hline (1) & 5G mobile networks spread COVID-19 & 1.70 & $(1.20)$ & 0.850 & 1.61 & $(1.06)$ & 0.815 & 1.73 & $(1.19)$ & 0.831 & 1.61 & $(1.14)$ & 0.881 \\
\hline (2) & COVID-19 will go away with cold weather & 1.79 & $(1.20)$ & 0.871 & 1.74 & $(1.13)$ & 0.878 & 1.85 & $(1.24)$ & 0.862 & 1.65 & $(1.13)$ & 0.893 \\
\hline (3) & $\begin{array}{c}\text { As a foreign disease, only foreigners can } \\
\text { catch COVID-19 }\end{array}$ & 1.63 & $(1.20)$ & 0.895 & 1.53 & $(1.08)$ & 0.894 & 1.71 & $(1.21)$ & 0.899 & 1.49 & $(1.11)$ & 0.926 \\
\hline (4) & Drinking bleach will prevent COVID-19 infection & 1.61 & $(1.19)$ & 0.875 & 1.57 & (1.12) & 0.888 & 1.71 & (1.18) & 0.862 & 1.49 & (1.09) & 0.893 \\
\hline (5) & $\begin{array}{l}\text { Consuming garlic will prevent } \\
\text { COVID-19 contraction }\end{array}$ & 1.95 & $(1.28)$ & 0.867 & 1.90 & $(1.20)$ & 0.840 & 2.02 & (1.27) & 0.832 & 1.81 & $(1.20)$ & 0.865 \\
\hline (6) & $\begin{array}{l}\text { Adding pepper to meals will prevent } \\
\text { COVID-19 infection }\end{array}$ & 1.78 & $(1.21)$ & 0.892 & 1.75 & (1.15) & 0.869 & 1.86 & (1.25) & 0.862 & 1.64 & (1.14) & 0.881 \\
\hline (7) & $\begin{array}{l}\text { Hydroxychloroquine is a sure defense from } \\
\text { COVID-19 contraction }\end{array}$ & 2.25 & $(1.31)$ & 0.720 & 2.29 & (1.25) & 0.701 & 2.30 & (1.29) & 0.705 & 2.12 & (1.23) & 0.700 \\
\hline (8) & $\begin{array}{l}\text { Drinking hard liquor protects you from COVID-19 } \\
\text { infection }\end{array}$ & 1.79 & $(1.24)$ & 0.877 & 1.71 & $(1.15)$ & 0.874 & 1.81 & $(1.22)$ & 0.880 & 1.61 & (1.12) & 0.875 \\
\hline (9) & Hand dryers kill the COVID-19 virus & 2.03 & $(1.21)$ & 0.790 & 2.04 & $(1.17)$ & 0.756 & 2.06 & $(1.21)$ & 0.775 & 1.94 & $(1.14)$ & 0.774 \\
\hline (10) & $\begin{array}{l}\text { If you do not believe COVID-19 exists you will not } \\
\text { contract it }\end{array}$ & 1.66 & $(1.17)$ & 0.877 & 1.62 & $(1.17)$ & 0.886 & 1.80 & $(1.22)$ & 0.877 & 1.57 & $(1.16)$ & 0.921 \\
\hline (11) & $\begin{array}{l}\text { If you can hold your breath for a prolonged period, } \\
\text { you are COVID-19 virus-free }\end{array}$ & 1.77 & $(1.23)$ & 0.875 & 1.73 & $(1.15)$ & 0.832 & 1.88 & $(1.20)$ & 0.846 & 1.65 & $(1.10)$ & 0.854 \\
\hline (12) & Houseflies spread COVID-19 & 2.06 & $(1.20)$ & 0.772 & 2.06 & $(1.15)$ & 0.708 & 2.10 & $(1.26)$ & 0.777 & 1.99 & $(1.13)$ & 0.728 \\
\hline
\end{tabular}

\subsection{COVID-19 Transmission Misinformation Consensus}

The transmission rumors presented to participants were debunked by the scientific community and not proven true by reputable researchers/sources [16,75]. Responses rated 1-definitely false, 2-probably false, and 3-not sure/cannot decide were counted as believe as not true (i.e., dummy coded as 0 ). Responses rated 4 -probably true and 5-definitely true were counted as believe as true (i.e., dummy coded as 1 ). This followed the dichotomous scoring method used for generic conspiracy beliefs to evaluate percentage of the sample to believe statements as false [101]. Table 3 illustrates frequencies and percentages of the twelve items believed not true. The percentages were out of 2433 total participants over the four studies. A consensus represents the level of agreement for appropriate construction of an objective measure [102]. For true/false measures, Clark and Watson (1995) stated that "virtually everyone (e.g., 95\% or more) either endorses or denies" statements with Likert formatted ratings producing similar results. The CTMS items had over $80 \%$ consensus with many approaching $90 \%$. This was overall high, given the range of news sources and variety of misinformation spread during the COVID-19 pandemic. Skewness (less than \pm 2 ) and kurtosis (less than \pm 7 ) was within acceptable ranges that did not substantially depart from normality $[109,110]$. The CTMS was intended as a specific true/false type scale to identify misinformation believers based on the large sample and this consensus. 
Table 3. Descriptive statistics of items considered COVID-19 transmission misinformation.

\begin{tabular}{|c|c|c|c|c|c|c|}
\hline & Frequency Believe Not True & Percent Believe Not True & Mean & SD & Skewness & Kurtosis \\
\hline Item 1 & 2155 & $88.57 \%$ & 1.66 & $(1.15)$ & 1.59 & 1.30 \\
\hline Item 2 & 2114 & $86.89 \%$ & 1.76 & (1.17) & 1.31 & 0.44 \\
\hline Item 3 & 2132 & $87.63 \%$ & 1.59 & (1.15) & 1.76 & 1.67 \\
\hline Item 4 & 2139 & $87.92 \%$ & 1.59 & $(1.14)$ & 1.77 & 1.71 \\
\hline Item 5 & 2043 & $83.97 \%$ & 1.92 & $(1.24)$ & 1.03 & -0.27 \\
\hline Item 6 & 2113 & $86.85 \%$ & 1.76 & (1.19) & 1.36 & 0.58 \\
\hline Item 7 & 1973 & $81.09 \%$ & 2.24 & $(1.27)$ & 0.53 & -0.93 \\
\hline Item 8 & 2119 & $87.09 \%$ & 1.73 & (1.18) & 1.44 & 0.82 \\
\hline Item 9 & 2082 & $85.57 \%$ & 2.02 & (1.18) & 0.86 & -0.40 \\
\hline Item 10 & 2124 & $87.30 \%$ & 1.66 & (1.18) & 1.66 & 1.40 \\
\hline Item 11 & 2122 & $87.22 \%$ & 1.76 & (1.17) & 1.34 & 0.46 \\
\hline Item 12 & 2105 & $86.52 \%$ & 2.05 & (1.18) & 0.78 & -0.47 \\
\hline
\end{tabular}

Notes: Responses 1-definitely false, 2-probably false, and 3-not sure/cannot decide counted as believe as not true. Responses 4 probably true and 5-definitely true counted as believe as true. Percent out of 2433 COVID-19 transmission misinformation item responses. All misinformation statements had responses that ranged from 1 to 5 . Means, standard deviations, skewness, and kurtosis based on the 5-point scale. Each statement was unproven at the time of the study.

\subsection{Demographic Variables}

The researchers collected demographic information regarding gender, age, education, average weekly hours of news watched, and level of religiosity. Education was assessed by the highest level of degree completed. Religiosity was measured averaging two items ("Religion/spirituality was an important part of my up bringing" and "I currently consider myself to be a member of a religious or spiritual organization") on a 7-point scale (strongly disagree -1 to strongly agree- 7 ).

Table 4 illustrates demographic frequencies and percentages. Of the total number of participants across the four studies $(N=2433), 65 \%$ were female. The average age was 41 years old (range $=19-88$ years old). An associate degree or higher was earned by $70 \%$ of participants. Each week on average $3.84 \mathrm{~h}$ of news was watched. Participants averaged 4.25 on the 7-point religiosity scale. The participants represented the ethnically diverse U.S.A. with 1915 Caucasians, 118 Hispanics/Latinos, 208 African Americans, 26 Native Americans, 126 Asians, and 40 identifying as other.

Table 4. Demographic Characteristics of Participants $(N=2433)$.

\begin{tabular}{ccc}
\hline Demographic Characteristics & Frequency & Percentage \\
\hline Gender & & 34.48 \\
\hline Male & 1594 & 65.52 \\
\hline Female & & \\
\hline Age range (years) & 467 & 19.19 \\
\hline $18-29$ & 762 & 31.34 \\
\hline $30-39$ & 519 & 21.33 \\
\hline $40-49$ & 399 & 16.4 \\
\hline $50-59$ & 286 & 11.76 \\
\hline 60 and over & & 4.56 \\
\hline Household Income & 111 & 7.07 \\
\hline Less than $\$ 10,000$ & 172 & 9.86 \\
\hline$\$ 10,000-19,999$ & 240 & 13.36 \\
\hline$\$ 20,000-29,999$ & 325 &
\end{tabular}


Table 4. Cont.

\begin{tabular}{ccc}
\hline Demographic Characteristics & Frequency & Percentage \\
\hline$\$ 40,000-49,999$ & 276 & 11.34 \\
\hline$\$ 50,000-59,999$ & 349 & 14.34 \\
\hline$\$ 60,000-69,999$ & 186 & 7.64 \\
\hline$\$ 70,000-79,999$ & 177 & 7.27 \\
\hline$\$ 80,000-89,999$ & 152 & 6.25 \\
\hline$\$ 90,000-99,999$ & 131 & 5.38 \\
\hline$\$ 100,000$ and over & 314 & 12.91 \\
\hline Ethnicity & & 78.71 \\
\hline Caucasian & 1915 & 4.85 \\
\hline Hispanic/Latino & 118 & 8.55 \\
\hline African American & 208 & 1.07 \\
\hline Native American & 26 & 5.18 \\
\hline Asian & 126 & 1.64 \\
\hline Other & 40 &
\end{tabular}

\section{Results}

\subsection{Phase 2 Reliability}

Table 5 displays reliability, variable means, standard deviations, and correlations to the CTMS in each of the four studies. Across the four studies, high reliability was present. These results evinced the 12-item CTMS had high internal consistency. The 12-items represented a wide range of different unfounded claims on COVID-19 transmission circulated, from treatment by drinking bleach and spread from houseflies. The high reliability demonstrated that participants showed high consistency in believing or not believing the gamut of false statements. High reliability scales have demonstrated acceptable construct validity to measure what they intended [111-113].

Table 5. Bivariate correlations of the 12-item COVID-19 Transmission Misinformation Scale (CTMS) with variables and demographics.

\begin{tabular}{|c|c|c|c|c|c|c|c|c|c|c|c|c|c|c|c|c|}
\hline \multirow[b]{2}{*}{ Variables } & \multirow[b]{2}{*}{$\mathbf{M}$} & \multicolumn{2}{|c|}{ Study 1} & \multicolumn{5}{|c|}{ Study 2} & \multirow[b]{2}{*}{$\mathbf{M}$} & \multicolumn{3}{|c|}{ Study 3} & \multicolumn{4}{|c|}{ Study 4} \\
\hline & & (SD) & $\mathbf{r}$ & & $\mathbf{M}$ & (SD) & $\mathbf{r}$ & & & (SD) & $\mathbf{r}$ & & $\mathbf{M}$ & (SD) & $\mathbf{r}$ & \\
\hline Fear of COVID-19 & 3.52 & -1.72 & 0.506 & $* * *$ & 3.37 & -1.64 & 0.487 & $* * *$ & 3.56 & -1.61 & 0.565 & $* * *$ & 3.3 & -1.61 & 0.486 & $* * *$ \\
\hline Callousness & - & - & - & & - & - & - & & 3.03 & -1.26 & 0.789 & $* * *$ & 2.35 & -1.43 & 0.736 & $* * *$ \\
\hline Conscientious & 5.06 & -1.05 & -0.408 & $* * *$ & 5 & -0.96 & -0.422 & $* * *$ & - & - & - & - & - & - & - & \\
\hline Conservatism & 4.43 & -0.95 & 0.164 & $* * *$ & 4.37 & -0.92 & 0.139 & $* * *$ & - & - & - & - & - & - & - & \\
\hline $\begin{array}{c}\text { Generic } \\
\text { Conspiracy Belief } \\
\text { Scale }\end{array}$ & 2.82 & -1.01 & 0.605 & $* * *$ & 2.88 & -0.99 & 0.556 & $* * *$ & - & - & - & - & - & - & - & \\
\hline PANAS & - & - & - & & 1.25 & -1.38 & -0.168 & $* * *$ & - & - & - & - & - & - & - & \\
\hline $\begin{array}{c}\text { Perceived } \\
\text { Vulnerability to } \\
\text { Disease }\end{array}$ & - & & & & & & & & 4.31 & -0.8 & -0.092 & $* * *$ & 4.33 & -0.84 & -0.106 & $* * *$ \\
\hline Variety Seeking & - & & & & & & & & 4.51 & -1.08 & -0.186 & $* * *$ & - & - & - & \\
\hline Risk Taking & - & & & & & & & & 2.73 & -1.54 & 0.75 & $* * *$ & 2.37 & -1.45 & 0.678 & $* * *$ \\
\hline Compassion & - & & & & & & & & & & & & 5.46 & -1.1 & -0.55 & $* * *$ \\
\hline
\end{tabular}


Table 5. Cont.

\begin{tabular}{|c|c|c|c|c|c|c|c|c|c|c|c|c|c|c|c|c|}
\hline \multirow[b]{2}{*}{ Variables } & \multirow[b]{2}{*}{$\mathbf{M}$} & \multicolumn{2}{|c|}{ Study 1} & \multicolumn{5}{|c|}{ Study 2} & \multirow[b]{2}{*}{$\mathbf{M}$} & \multicolumn{3}{|c|}{ Study 3} & \multicolumn{4}{|c|}{ Study 4} \\
\hline & & (SD) & $\mathbf{r}$ & & $\mathbf{M}$ & (SD) & $\mathbf{r}$ & & & (SD) & $\mathbf{r}$ & & $\mathbf{M}$ & (SD) & $\mathbf{r}$ & \\
\hline $\begin{array}{l}\text { Wearing a Mask } \\
\text { in Public }\end{array}$ & - & & & & & & & & & & & & 6.36 & -1.19 & -0.301 & $* * *$ \\
\hline $\begin{array}{c}\text { Demographic } \\
\text { Characteristics }\end{array}$ & & & & & & & & & & & & & & & & \\
\hline Gender (Female) & 1.66 & -0.48 & -0.265 & $* * *$ & 1.66 & -0.47 & -0.172 & $* * *$ & 1.64 & -0.48 & -0.284 & $* * *$ & 1.66 & -0.48 & -0.279 & $* * *$ \\
\hline Age & 42.34 & -13.45 & -0.158 & $* * *$ & 41.25 & -12.93 & -0.123 & $* * *$ & 41.97 & -13.34 & -0.183 & $* * *$ & 41.06 & -13.28 & -0.077 & $* * *$ \\
\hline College Degree & 0.71 & -0.45 & 0.218 & $* * *$ & 0.69 & -0.46 & 0.147 & $* * *$ & 0.72 & -0.45 & 0.258 & $* * *$ & 0.69 & -0.46 & 0.121 & $* *$ \\
\hline $\begin{array}{l}\text { Average Weekly } \\
\text { News (Hours) }\end{array}$ & 4.13 & -2.65 & 0.166 & $* * *$ & 3.68 & -2.64 & 0.242 & $* * *$ & 3.99 & -2.62 & 0.233 & $* * *$ & 3.62 & -2.66 & 0.184 & $* * *$ \\
\hline Religiosity & 4.58 & -1.93 & 0.339 & $* * *$ & 4.25 & -1.93 & 0.339 & $* * *$ & 4.63 & -1.85 & 0.295 & $* * *$ & 4.22 & -1.99 & 0.317 & $* * *$ \\
\hline
\end{tabular}

Note: ** $p<0.01, * * *<0.001$. Gender was dummy coded with males as 1 and females as 2 . College degree was dummy coded with those with an associate degree or higher as 1 and those without 0 . Religiosity was measured averaging two items ("Religion/spirituality was an important part of my up bringing" and "I currently consider myself to be a member of a religious or spiritual organization") on a 7-point scale (strongly disagree- 1 to strongly agree-7).

\subsection{Convergent and Discriminant Validity}

Correlations across a variety of measures were examined to assess discriminant validity and uniqueness as a measure [114,115]. The researchers correlated the CTMS with the following measures: fear of COVID-19 (i.e., degree of fear to the novel coronavirus) $($ alpha $=0.82)[116]$, callousness (i.e., rigidity in ideas) $($ alpha $=0.85)[81,88]$, conscientious (i.e., following rules $/$ norms) (alpha $=0.81$ ) [117], conservatism (i.e., right-wing ideology) $($ alpha $=0.83)[118]$, generic conspiracy beliefs (i.e., credence to unproven conspiracies) (alpha $=0.95)$ [101], Positive and Negative Affect Schedule (PANAS) (i.e., state of emotions) (alpha $=0.87)$ [119], perceived vulnerability to disease (i.e., estimated harm of illnesses) $($ alpha $=0.82)$ [120], variety seeking (i.e., diversity in selection) $($ alpha $=0.81)$ [121], risk taking (i.e., exposure to threats/dangers) (alpha $=0.85$ ) [83], and compassion (i.e., concern for suffering) (alpha $=0.84)$ [122]. Correlation is not evidence to support causation. However, it does indicate the degree of relatedness and evidences that a measure differs from another [123]. Measures significantly correlated with the 12-item CTMS. The results supported expected relationships with other measures. Across the four studies, fear of COVID-19 demonstrated a consist middling correlation with the CTMS.

Conscientious (study 1: $\mathrm{r}=-0.408, p<0.001$; study $2: \mathrm{r}=-0.422, p<0.001$ ), variety seeking (study 3: $\mathrm{r}=-0.092, p<0.001$ ), and compassion (study 4: $\mathrm{r}=-0.301, p<0.001$ ) demonstrated a negative correlation with the CTMS. Meanwhile, conservatism (study 1 : $\mathrm{r}=0.164, p<0.001$; study 2: $\mathrm{r}=0.139, p<0.001$ ) and generic conspiracy beliefs (study 1 : $\mathrm{r}=0.605, p<0.001$; study $2: \mathrm{r}=0.556, p<0.001$ ) positively correlated with the CTMS.

Further, callousness (study 3: $\mathrm{r}=0.789, p<0.001$; study 4: $\mathrm{r}=0.736, p<0.001$ ) demonstrated a positive correlation with the CTMS. Higher CTMS scores correlated with higher risk-taking scores (study 3: $\mathrm{r}=0.750, p<0.001$; study $4: \mathrm{r}=0.678, p<0.001$ ) and lower personal vulnerability to disease scores (study 3: $\mathrm{r}=-0.092, p<0.001$; study $4: \mathrm{r}=-0.106$, $p<0.001$ ). A wide range of correlated measures provided support for convergent and discriminant validity.

\subsection{Study 4 Moderated Mediation Analysis \\ Phase 3 Measures}

Independent variable. Fear of COVID-19 measures the degree of COVID-19 phobia using seven items on a five-point scale from (1-strongly disagree to 5-strongly agree) $(a l p h a=0.88)[116]$. For example, an item states: "My heart races or palpitates when I think about getting coronavirus-19".

Dependent variable. Wearing a mask in public around others and in enclosed spaces (e.g., grocery stores) was mandated because of knowing the transmission method of 
COVID-19 infection. Wearing a mask in public was a fundamental practice to decrease communal spread of the disease [124]. The intention to wear a mask in public was measured on a seven-point scale ("I wear a face covering in public" from 1-strongly disagree to 7-strongly agree).

Moderator. Callousness is the degree someone lacks empathy and sympathy for others [81,87]. It was measured using the CAT-PD short seven-item scale (e.g., "Do not care how my actions affect others"). The measure demonstrated high reliability (alpha $=0.85$ ).

\subsection{Predictive Validity Results}

Moderated mediation analysis was conducted using SPSS PROCESS V3.5 software $[125,126]$ (see Table 6 and Figure 2). The 10,000 bootstrapped sampling procedure was applied for estimations [127]. There was mean centering of variables. Statistical significance was considered at the $95 \%$ confidence interval and when zero was not in between confidence intervals. Wearing a mask in public was overall high among participants on the seven-point scale $(M=6.36, S E=1.19)$.

Table 6. Study 4 moderated mediation results of fear of COVID-19 and wearing a mask in public.

\begin{tabular}{|c|c|c|c|c|c|c|c|c|}
\hline \multirow[b]{3}{*}{ Antecedent } & \multicolumn{8}{|c|}{ Outcome } \\
\hline & \multicolumn{4}{|c|}{$\begin{array}{l}\text { COVID-19 Transmission } \\
\text { Misinformation Beliefs }\end{array}$} & \multicolumn{4}{|c|}{ Wearing a Mask in Public } \\
\hline & Coeff. & $S E$ & $t$ & $p$ & Coeff. & $S E$ & $t$ & $p$ \\
\hline Fear of COVID-19 & 0.128 & 0.014 & 8.973 & $<0.0001$ & 0.265 & 0.031 & 8.456 & $<0.0001$ \\
\hline $\begin{array}{c}\text { COVID-19 Transmission Misinformation } \\
\text { Scale (CTMS) }\end{array}$ & - & - & - & - & -0.617 & 0.084 & -7.315 & $<0.0001$ \\
\hline Callousness & 0.295 & 0.018 & 16.223 & $<0.0001$ & -0.156 & 0.045 & -3.486 & $<0.001$ \\
\hline Fear of COVID-19 $\times$ Callousness & 0.124 & 0.009 & 14.202 & $<0.0001$ & 0.118 & 0.021 & 5.678 & $<0.0001$ \\
\hline \multicolumn{9}{|l|}{ Covariates } \\
\hline Gender (female) & -0.16 & 0.047 & -3.407 & $<0.001$ & 0.139 & 0.097 & 1.429 & 0.154 \\
\hline Age & -0.001 & 0.002 & -0.46 & 0.645 & 0 & 0.003 & -0.096 & 0.924 \\
\hline College Degree & -0.044 & 0.046 & -0.954 & 0.34 & 0.07 & 0.094 & 0.747 & 0.456 \\
\hline Weekly Hours of News (Average) & -0.008 & 0.009 & -0.964 & 0.336 & 0.023 & 0.018 & 1.321 & 0.187 \\
\hline Religiosity & 0.057 & 0.011 & 5.11 & $<0.0001$ & -0.051 & 0.023 & -2.21 & $<0.05$ \\
\hline Model Summary & \multicolumn{4}{|c|}{$\mathrm{R}^{2}=0.727$} & \multicolumn{4}{|c|}{$\mathrm{R}^{2}=0.246$} \\
\hline & \multicolumn{4}{|c|}{$\mathrm{F}(8,593)=197.227, p<0.0001$} & \multicolumn{4}{|c|}{$\mathrm{F}(9,592)=21.502, p<0.0001$} \\
\hline
\end{tabular}

Notes: The 12-Item COVID-19 Transmission Misinformation Scale was the mediator in the model. Variables were mean centered. Gender was dummy coded with males as 1 and females as 2 . College degree was dummy coded 0 without and 1 with an associate degree or higher.

A omnibus test of moderated mediation of callousness and COVID-19 transmission misinformation beliefs demonstrated a significant indirect effect with fear of COVID-19 on wearing a mask in public (effect $=-0.077, S E=0.014$ (LLCI -0.108 ULCI -0.052$)$ ) $[127,128]$. Greater fear of COVID-19 was associated with greater masking wearing in public $(t(592)=8.496$, $S E=0.031, p<0.0001$ (LLCI 0.203 ULCI 0.326)) (H1). Greater fear of COVID-19 was associated with greater COVID-19 transmission misinformation beliefs $(t(593)=8.973, S E=0.014$, $p<0.0001$ (LLCI 0.010 ULCI 0.156)) (H2). Greater COVID-19 transmission misinformation belief was associated with decreased mask wearing in public $(t(592)=-7.315, S E=0.084$, $p<0.0001$ (LLCI - 0.782 ULCI - 0.451)) (H3) [129]. Someone fearful of COVID-19 expressed greater intent to wear a mask in public; however, in the presence of greater belief in COVID-19 transmission misinformation, their intent decreased. In other words, those more fearful who reviewed and believed transmission rumors displayed lower mask wearing intent. For example, someone fearful but who ate garlic the night before may be less concerned about wearing a mask for protection because they falsely believe garlic pro- 
tects against transmission. Adequate fit was demonstrated based on SPSS AMOS V25 modeling following recommended thresholds $\left(\chi^{2} / \mathrm{df}=3.998, p<0.0001\right.$, RMSEA $=0.071$, SRMR $=0.077, \mathrm{CFI}=0.943)[130,131]$.

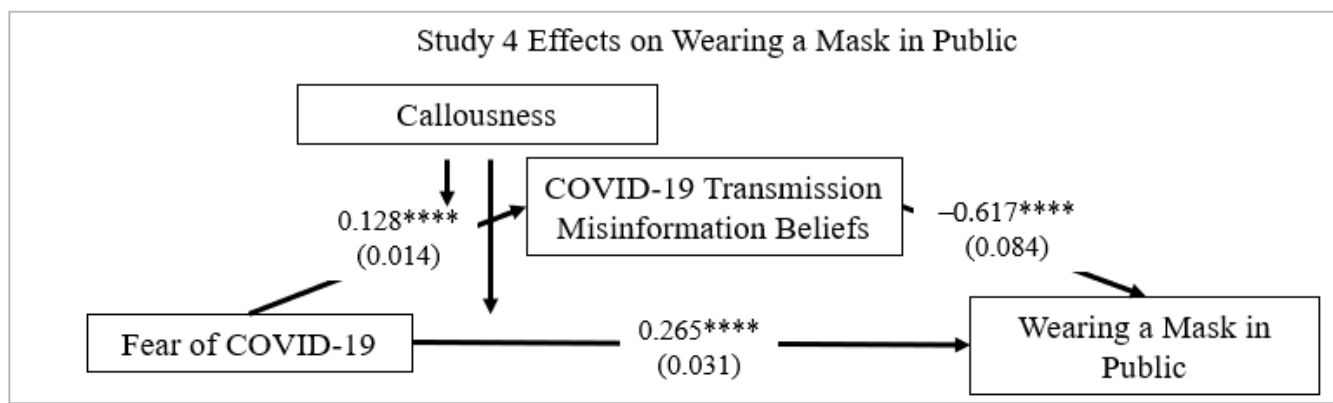

Note: Model utilized 12-item COVID-19 Transmission Misinformation Scale (CTMS). Gender, age, college degree, average weekly hours of news, and religiosity were covariates. $* * * *=\mathrm{p}<0.0001$

Figure 2. Study 4 effects on wearing a mask in public model estimates.

The researchers included age, gender, college degree, average weekly hours of news, and religiosity as covariates in the moderated mediation model. The model with and without the covariates shared the same pattern of statistical significance and direction of relationships.

\subsection{Moderated Mediation Results}

Figure 3 illustrates moderated mediation results with callousness and fear of COVID19 on CTMS scores and wearing a mask in public. Results were bootstrapped with the SPSS PROCESS V3.5 10,000 resampling procedure at the 95\% confidence interval [128]. Table 7 shows the confidence intervals for the moderated effects. Moderated mediation analysis with low callousness and high fear of COVID-19 attenuated wearing a mask in public (effect $=0.085$, LLCI 0.056 to ULCI 0.114) (H4). However, high callousness and fear of COVID-19 exacerbated COVID-19 transmission misinformation beliefs (effect $=0.224$, LLCI 0.163 to ULCI 0.285) (H5). This indirect conditional path decreased wearing a mask in public (effect $=-0.052$, LLCI -0.077 to ULCI -0.032 ).

Table 7. Study 4 conditional direct and indirect effects with callousness as moderator.

\begin{tabular}{cccc}
\hline & Left-Leaning & Average & Right-Leaning \\
\hline & Low (-1 SD) & Mean & High (+1 SD) \\
\hline Fear of COVID-19 $\rightarrow$ & -0.040 (LLCI - & 0.085 (LLCI 0.056 & 0.333 (LLCI 0.295 \\
Wearing a Mask in Public & 0.077 ULCI - 0.002) & ULCI 0.114) & ULCI 0.372) \\
Fear of COVID-19 $\rightarrow$ CTMS & 0.106 (LLCI 0.029 & 0.224 (LLCI 0.163 & 0.460 (LLCI 0.363 \\
Fear of COVID-19 $\rightarrow$ CTMS & ULCI 0.183) & ULCI 0.285) & ULCI 0.557) \\
$\rightarrow$ Wearing a Mask & 0.024 (LLCI 0.003 & -0.052 (LLCI - & -0.206 (LLCI - \\
in Public & ULCI 0.051) & 0.077 ULCI - 0.032) & 0.287 ULCI - 0.143)
\end{tabular}

Note: Bootstrap 10,000 resampled confidence intervals, CTMS = 12-item COVID-19 Transmission Misinformation Scale. 


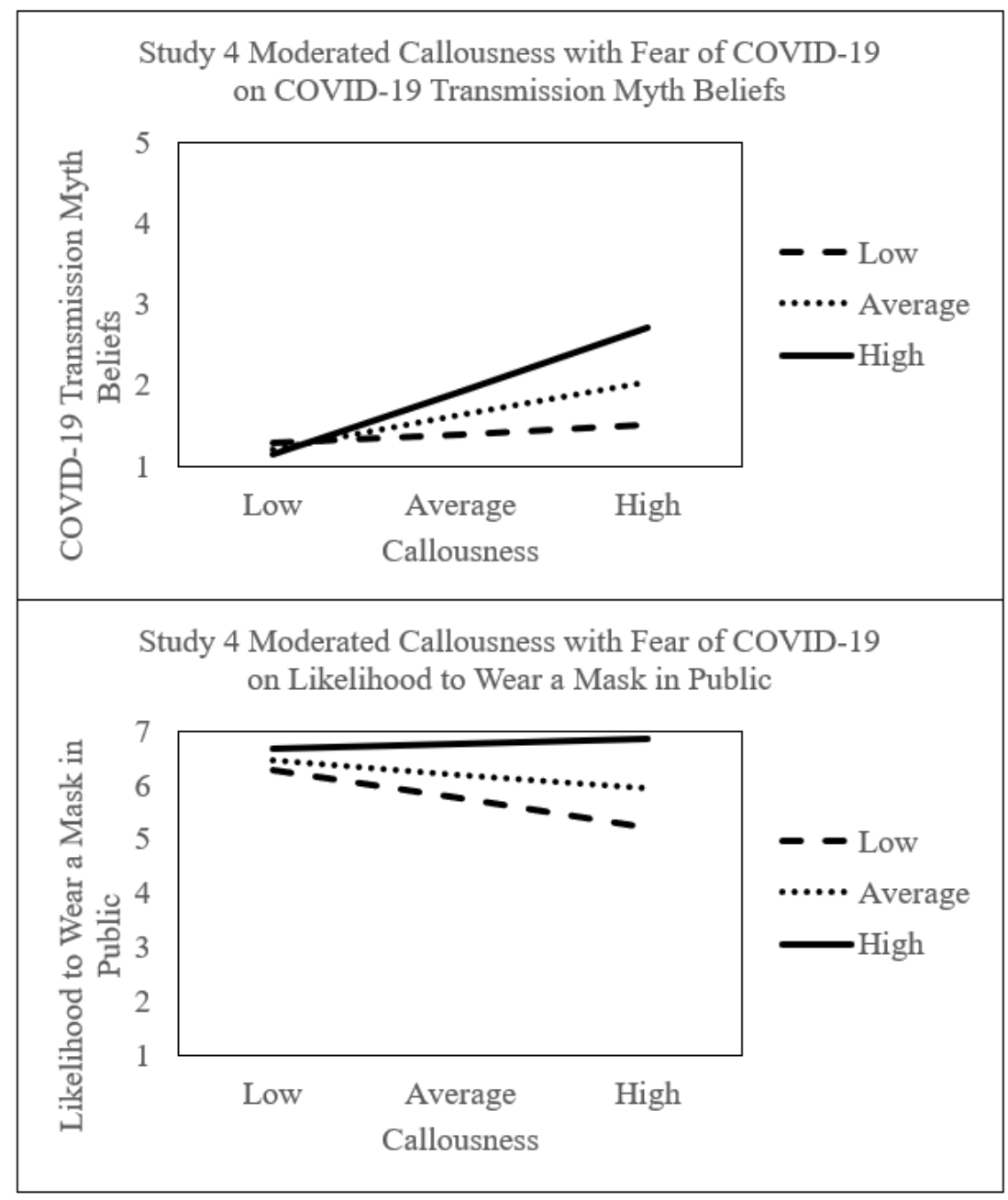

Figure 3. Indirect conditional effects with fear of COVID-19 and callousness.

\section{Discussion}

Rigorous design and objective procedures refined the large initial set of items into a succinct list. Across four studies, the researchers designed and generated the 12-item CTMS. The CTMS demonstrated high reliability with each dataset. Compared to a wide range of measures, the CTMS evinced uniqueness. The CMTS demonstrated convergent validity with the fear of COVID-19, callousness, generic conspiracy beliefs, risk-taking, and conservatism. Meanwhile, the CTMS diverged with personal vulnerability to disease, compassion, and conscientiousness.

Furthermore, correlational results provided insights into demographic differences. Males, younger aged, college educated, and religiosity associated with greater COVID-19 transmission misinformation beliefs. These results corroborate prior research that found males and younger individuals were less concerned with COVID-19 risks and partaking in health-protective behaviors [132]. For persons without a college degree, understanding of COVID-19 transmission may relate to essential work positions and personal experiences. For example, grocery store workers interacted with enumerate customers and company policies mandated facial covering. Daily, their personal well-being was at risk, and many had to enforce company policies. Many essential workers did not have the luxury to work from home. Community cooperation to public health policies acted as their main source of protection. COVID-19 was perceived as a real health threat to essential workers. First-hand experience and/or knowing people with the disease can change minds.

In addition, viewing more news on average each week correlated with higher CTMS scores. More news does not mean more well informed. In fact, results indicated more 
misinformation in someone's cognition. Sorting and decerning fact versus rumor leaned towards believing COVID-19 transmission misinformation. The existence of misinformation in society is an ongoing problem in the battle against COVID-19.

Meanwhile, the strong correlational relationship between callousness and COVID-19 transmission misinformation beliefs may be explained by the lack of willingness to hear and learn from others such as scientists stating to wear a mask to protect others. The researchers mean centered variables in the moderated mediation PROCESS analysis and assessed standardized effects to account for any potential multicollinearity issues [126].

Fear of COVID-19 moderated by callousness increased mask wearing in public. This suggests that early public health messaging can stick with callous individuals. For instance, wearing a mask properly in public acts as a primary physical defense to repel respiratory droplets that carry the COVID-19 virus between people. Such messaging helps to inform the public about the dangers and to take preventative action.

However, mediation analysis illustrated that greater COVID-19 transmission misinformation beliefs decreased mask wearing in public. Moderated mediation results evinced that greater callousness with greater COVID-19 fears are more likely to believe transmission rumors and thereby exacerbated not wearing a mask in public. The inception of information for callous individuals may pose insurmountable reeducation challenges if misinformation beliefs solidify.

Hearsay stating that face coverings do not work arguably resulted in needless infections and lost lives, many through asymptomatic transmission [20]. The use of this measure to study human behaviors can assist in flattening the curve. Research using the CTMS can also provide insights in combating the next cycle of rumors to the future disease that will grip the world.

\section{Implications}

Scientists study the transmission of infectious diseases so that the public can adopt preventative behaviors. Public health officials inform the public with facts from rigorous controlled studies. They design public policies that mitigate risks which have saved countless lives. Despite the rapid testing and release of accurate COVID-19 transmission information by public health officials, misinformation took hold in society. If COVID-19 is falsely believed to not be transmitted by respiratory air droplets, what are these misinformation believers doing to take preventative measures? Across the four CTMS studies, religiosity was positively correlated to the CTMS, indicating religion as a source of misinformation to COVID-19 transmission. Many misinformation believers received COVID-19 information from their religious organizations and believed prayer protected from infection $[133,134]$. While the act of praying and community provide other benefits, there is no scientifically studied evidence that prayer prevents COVID-19 infections [133]. In fact, large in-person gatherings with bunching in close proximities are known as superspreader events $[58,135,136]$. The false belief that in-person religious gatherings protect against transmission inadvertently spreads the disease $[137,138]$. Understanding this logic can help public health officials to reach these groups. The CTMS provides a tool for researchers to identify this subgroup and discover relationships to other variables.

Is misinformation causing losses to providing immediate healthcare or do the losses extend further? The misleading videos filming local hospitals showing empty waiting rooms and parking lots during the COVID-19 pandemic fostered an environment of mistrust in health institutions $[54,55]$. Although most patients are instructed to quarantine at home because of the highly contagious nature of COVID-19, the misinformation cast doubt on the number of cases and deaths reported by the CDC and reputable health institutions. If hospital ICU beds and respirator units are outnumbered by patients, one could imagine full hospitals resembling a packed football stadium on gameday. This contradictory information posed a problem for health institutions advising the public how the virus is spread and how preventative measures (e.g., face coverings and physical distancing) can save lives. The false empty hospital narrative suggests there is no real pandemic and not to trust 
health institutions. In addition to the service time lost to provide patient care, transmission misbeliefs contributed to citizens performing risky behaviors that transferred the disease through communal spread (e.g., large indoor gatherings and weddings) [135,138].

Furthermore, there are damaging long-term costs to this public mistrust in health institutions. Given the mutated variants of COVID-19 [139] and shelter-in-place public fatigue [140], the public may resist new developing scientific information. Public health institutions are effective if the public responds and changes behaviors to prevent the spread of disease. Of importance to public health is mitigating risks and public awareness. A lack of public cooperation undermines efforts. For example, facial coverings are known to work if they seal and cover air pathways (e.g., the nose and mouth). Improperly wearing a mask (e.g., exposing the nose while around others) will not effectively prevent contracting COVID-19. So even if the public begrudgingly participates in preventative measures to follow ordinances, individuals may still become sick because they choose to disregard health reports. This scale captures one aspect of COVID-19 misbeliefs that can help researchers study relationships with outcome variables.

Addressing rumors can accompany a dissemination plan. This can increase public understanding and cooperation in health care decisions. Widespread misinformation reduced participation in preventative behaviors (e.g., wearing a face mask in public) because it was believed that transmission was not through respiratory air droplets (e.g., it was misbelieved that transmission was through 5G network towers) [141]. Steffens et al. (2019) recommended openly communicating with evidence-informed responses to misinformation. Safe-space dialogue can help unravel narratives [142].

\section{Limitations}

This study collected survey responses months into the pandemic. The results demonstrated that COVID-19 transmission misinformation beliefs remained consistent and stable. Public health education discouraging the spread of misinformation appeared to stop the creation of widely recognized new COVID-19 transmission falsehoods. However, as time progresses, belief in these rumors may wane as individuals forget. For example, eyewitness recall of incidents can be influenced based on words used to asked to describe what happened [143]. Human memory is malleable and changes with new information [144]. The currency of the CTMS may shift overtime. Although society at large experienced major changes from the COVID-19 pandemic with lasting impressions, memories will fade. This is like forgetting the aftermath of the terrorist attacks of $9 / 11$, events from the last hurricane, or previous Olympic results. They become a distant memory, both present and possible to influence.

While this study measured mask wearing in public through self-reporting, evaluating proper mask wearing that covers someone's respiratory orifices (i.e., the nose and mouth) requires physical observation. Public health marketing has missed the initial opportunity to explain the purpose and correct way to cover air passages that reduce the transfer of respiratory droplets that carry the COVID-19 virus between people. In the first outbreak, global mask scarcity necessitated any form of mask be created (e.g., cut from t-shirts and garments). Masks varied in thickness and design. Masks can restrict the amount of oxygen breathed in by someone. Some people find them uncomfortable. Therefore, people wear them exposing their nose and covering their chins. Further observational research with the CTMS can reveal more insight into proper public health behaviors and cooperation.

The transmission of information, beliefs, and actions are not inherently linked $[145,146]$. The existence of rumors does not mean society will believe them or act on them. For example, politicians have capitalized in times of "chaos" for rumors to adhere and generate action [146]. Meanwhile, DiFonzo et al. (2013) studied how a consensus and reinforcement from others increased belief in rumors. The COVID-19 pandemic created unprecedented changes where many people sought out news and explanations in a time of moral panic [14]. Advancements in social media communication and societal lockdowns created an opportunity for unfounded claims to instantaneously spread during the initial outbreak [43,79]. As 
the pandemic continued, accurate information and debunked claims reduced new rumors from spreading $[45,100]$. Results from this study reflect a distinct circumstance where society, media, and national leaders experienced a collective period of uncertainty, followed by public health policies designed to mitigate contagion. Researchers are encouraged to holistically evaluate rumors, events, time, existing norms, and observed relationships when drawing inferences.

\section{Future Research}

Consuming media can act as a coping method for changes in our environment. Many sought information on social media platforms and news media outlets to understand COVID-19 which shared misinformation [6,79]. Greater media consumption coincided with added stressors such as homeschooling and job losses. Household commodities such as cleaning supplies provided comfort to consumers [147]. Future studies can investigate how COVID-19 transmission misinformation beliefs directed consumption. With false narratives (e.g., house flies transmit COVID-19), purchasing cleaning products would theoretically not protect someone from infection. It is hypothesized those still purchasing household goods are not transmission misinformation believers because these goods (e.g., hand sanitizers) relate to scientifically proven ways to prevent contraction of the disease.

Moreover, some misinformation believers become entrenched in their false narratives. For example, they may wrongfully believe COVID-19 is a conspiracy from international governments using $5 \mathrm{G}$ networks to take away personal freedoms and scientists are their devious agents. How do these misinformation believers react to facts presented on websites such as from the CDC or WHO? MRI studies could reveal which parts of the brain are activated among misinformation believers versus fact believers. It can provide neurological evidence for how misinformation believers react to counternarrative facts. It is postulated that misinformation believers will respond with an emotional rejection of the information visible in brain imaging.

Furthermore, this research can provide insights into how to change incorrect ideas about COVID-19 transmission. Are the CDC and WHO fact pages enough to counter misinformation? If misinformation believers actively reject and seek fake news sources that confirm their false narratives, how can health providers undo this damage? How can health providers practice medicine if misinformation believers are uncooperative? Best practices to dispel misinformation and reeducate are first steps to providing health care. Qualitative research with nurses and doctors who have worked with misinformation believers could catalog effective dispelling techniques. Researchers recommend listening and directly addressing vaccine misbeliefs as an approach [142]. However, are short medical appointments listening and providing facts enough when many actively read unscientific opinion pieces as truths?

While rumors generally have a negative connotation associated with the COVID-19 pandemic, rumors have historically had many benefits for society. Rumors can encourage healthy debate in democratic groups [61]. Rumors of COVID-19 transmission gave scientists reasons to investigate and eventually disprove claims that could have been true (e.g., cold weather will kill off the virus) [28]. Through process of elimination, a large body of evidence-based literature exists clearly debunking how the disease spreads. The list of CTMS items provides a concise list of likely rumors researchers can promptly investigate during the next pandemic. Reaching those callous and entrenched in misinformation communities will impact public health.

Public health officials have spent considerable time creating education materials to counter misinformation in each new health crisis $[57,79]$. To what degree does education make a difference? How do we educate those more prone to accept misinformation? Unfortunately, transmission inaccuracies are ubiquitous and continue to influence behaviors. For example, some people without preexisting conditions believed they had a degree of invulnerability to COVID-19, although the virus did not discriminate based on genes and current health conditions $[13,148]$. What kind of education is most effective in undoing 
rumors? Would teaching general virus reproduction and cellular biology help demystify the infection process, or would directly debunking rumors better serve the public? The laundry list of unfounded claims that wildly spread with new diseases can be circumvented by teaching basic epidemiology [57]. However, some falsehoods appear believable even with a basic understanding of biology. How can health experts spend less time with each new disease reeducating the public and more time saving lives? Future research can utilize the CTMS to identify misinformation believers and which method is more effective in dispelling rumors.

\section{Conclusions}

The CTMS provides a contextual tool in the infodemic battle against COVID-19. The CTMS quantifies the degree and amount of COVID-19 transmission misinformation respondents believe. Greater COVID-19 fear is associated with greater COVID-19 transmission misinformation beliefs, which is associated with lower mask wearing in public. This important tool provides a method for researchers to study behaviors and relationships with other variables. It is valuable to address contemporary problems (e.g., resistance to wearing a mask in public). Variants of COVID-19 exist. Diseases are becoming more deadly (e.g., Ebola) and contagious. The scientific community can expect the next infodemic while also preparing for the next pandemic.

Author Contributions: Conceptualization, S.B., D.E.M., E.A., M.L. and J.S.; Data curation, S.B.; Formal analysis, S.B.; Funding acquisition, S.B.; Investigation, E.A., M.L. and J.S.; Methodology, S.B.; Project administration, S.B. and D.E.M.; Resources, M.L. and J.S.; Validation, J.S.; Visualization, S.B. and M.L.; Writing—original draft, S.B., D.E.M. and E.A.; and Writing—review \& editing, S.B., D.E.M., E.A., M.L. and J.S. All authors have read and agreed to the published version of the manuscript.

Funding: Funding was provided by California State University, East Bay, College of Business and Economics professional development funds. The views expressed are those of the authors and not necessarily those of California State University, East Bay.

Institutional Review Board Statement: The study was conducted according to the guidelines of the Declaration of Helsinki and approved by the Institutional Review Board of California State University, East Bay (protocol CSUEB-IRB-2020-176 approved on 11 January 2021).

Informed Consent Statement: Informed consent was obtained from all subjects involved in the study.

Data Availability Statement: Due to the nature of this research, participants of this study did not agree for their data to be shared publicly, so supporting data is not available.

Conflicts of Interest: The authors declare no conflict of interest.

\section{References}

1. Ahmed, W.; Seguí, F.L.; Vidal-Alaball, J.; Katz, M.S. COVID-19 and the "Film Your Hospital" Conspiracy Theory: Social Network Analysis of Twitter Data. J. Med. Internet Res. 2020, 22, e22374. [CrossRef]

2. Bitan, D.T.; Grossman-Giron, A.; Bloch, Y.; Mayer, Y.; Shiffman, N.; Mendlovic, S. Fear of COVID-19 scale: Psychometric characteristics, reliability and validity in the Israeli population. Psychiatry Res. 2020, 289, 113100. [CrossRef]

3. Aiyewumi, O.; Okeke, M.I. The myth that Nigerians are immune to SARS-CoV-2 and that COVID-19 is a hoax are putting lives at risk. J. Glob. Health 2020, 10. [CrossRef]

4. Ali, S.; Asaria, M.; Stranges, S. COVID-19 and inequality: Are we all in this together? Can. J. Public Health 2020, 111, 415-416. [CrossRef]

5. Lee, A.M.; Allport, G.W.; Postman, L. The Psychology of Rumor. Am. Sociol. Rev. 1948, 13, 361. [CrossRef]

6. Allport, G.W.; Postman, L.J. The basic psychology of rumor. Trans. N. Y. Acad. Sci. 1945, 8, 61-81. [CrossRef] [PubMed]

7. Atrubin, D.; Wiese, M.; Bohinc, B. An outbreak of COVID-19 associated with a recreational hockey game-Florida, June. Morb. Mortal. Wkly. Rep. 2020, 69, 1492-1493. [CrossRef]

8. Avalos, L.; Tylka, T.L.; Wood-Barcalow, N. The Body Appreciation Scale: Development and psychometric evaluation. Body Image 2005, 2, 285-297. [CrossRef]

9. Bai, Y.; Yao, L.; Wei, T.; Tian, F.; Jin, D.-Y.; Chen, L.; Wang, M. Presumed Asymptomatic Carrier Transmission of COVID-19. JAMA 2020, 323, 1406. [CrossRef]

10. Basch, C.H.; Kecojevic, A.; Wagner, V.H. Coverage of the COVID-19 Pandemic in the Online Versions of Highly Circulated U.S. Daily Newspapers. J. Community Health 2020, 45, 1089-1097. [CrossRef] [PubMed] 
11. Beitler, J.R.; Mittel, A.M.; Kallet, R.; Kacmarek, R.; Hess, D.; Branson, R.; Olson, M.; Garcia, I.; Powell, B.; Wang, D.S.; et al. Ventilator Sharing during an Acute Shortage Caused by the COVID-19 Pandemic. Am. J. Respir. Crit. Care Med. 2020, 202, 600-604. [CrossRef]

12. Bendau, A.; Petzold, M.B.; Pyrkosch, L.; Maricic, L.M.; Betzler, F.; Rogoll, J.; Große, J.; Ströhle, A.; Plag, J. Associations between COVID-19 related media consumption and symptoms of anxiety, depression and COVID-19 related fear in the general population in Germany. Eur. Arch. Psychiatry Clin. Neurosci. 2021, 271, 283-291. [CrossRef]

13. Bentzen, J. In crisis, we pray: Religiosity and the COVID-19 pandemic. CEPR Press 2020, 20, 52-108.

14. Bode, L.; Vraga, E.K. See Something, Say Something: Correction of Global Health Misinformation on Social Media. Health Commun. 2017, 33, 1131-1140. [CrossRef]

15. Bowleg, L. We're not all in this together: On COVID-19, intersectionality, and structural inequality. Am. Public Health Assoc. 2020, 110, 917. [CrossRef] [PubMed]

16. Brennen, J.S.; Simon, F.; Howard, P.N.; Nielsen, R.K. Types, sources, and claims of COVID-19 misinformation. Reuters Inst. 2020, 7, 1-13.

17. Brezina, T.; Phipps, H.E., Jr. False news reports, folk devils, and the role of public officials: Notes on the social con-struction of law and order in the aftermath of Hurricane Katrina. Deviant Behav. 2009, 31, 97-134. [CrossRef]

18. Briggs, C.L.; Hallin, D.C. Making Health Public: How News Coverage is Remaking Media, Medicine, and Contemporary Life; Routledge: Oxford, UK, 2016.

19. Brotherton, R.; French, C.C.; Pickering, A.D. Measuring Belief in Conspiracy Theories: The Generic Conspiracist Beliefs Scale. Front. Psychol. 2013, 4, 279. [CrossRef] [PubMed]

20. Brown, T.S.; Walensky, R.P. Serosurveillance and the COVID-19 Epidemic in the US: Undetected, Uncertain, and Out of Control. JAMA 2020, 324, 749-751. [CrossRef] [PubMed]

21. Buhrmester, M.; Kwang, T.; Gosling, S.D. Amazon's Mechanical Turk: A New Source of Inexpensive, Yet High-Quality Data? American Psychological Association: Washington, DC, USA, 2016.

22. Byambasuren, O.; Cardona, M.; Bell, K.; Clark, J.; McLaws, M.-L.; Glasziou, P. Estimating the extent of asymptomatic COVID-19 and its potential for community transmission: Systematic review and meta-analysis. Off. J. Assoc. Med. Microbiol. Infect. Dis. Can. 2020, 5, 223-234. [CrossRef]

23. Calvillo, D.P.; Ross, B.J.; Garcia, R.J.B.; Smelter, T.J.; Rutchick, A.M. Political Ideology Predicts Perceptions of the Threat of COVID-19 (and Susceptibility to Fake News About It). Soc. Psychol. Pers. Sci. 2020, 11, 1119-1128. [CrossRef]

24. Cardinale, E.M.; Marsh, A.A. The reliability and validity of the Inventory of Callous Unemotional Traits: A meta-analytic review. Assessment 2020, 27, 57-71. [CrossRef] [PubMed]

25. Carpenter, S. Ten Steps in Scale Development and Reporting: A Guide for Researchers. Commun. Methods Meas. 2017, 12, 25-44. [CrossRef]

26. Castaneda, M.A.; Saygili, M. The Effect of Shelter-in-Place Orders on Social Distancing and the Spread of the COVID-19 Pandemic: A Study of Texas. Front. Public Health 2020, 8, 596607. [CrossRef] [PubMed]

27. Center for Disease Control and Prevention. About Cloth Face Coverings. Coronavirus Disease 2019 (COVID-19). Available online: https://www.google.com.hk/url?sa=t\&rct=j\&q=\&esrc=s\&source=web\&cd=\&ved=2ahUKEwj9-sHRxOzzAhXRc9 4KHex7CE0QFnoECAgQAQ\&url=https\%3A\%2F\%2Fstacks.cdc.gov\%2Fview\%2Fcdc\%2F89934\%2Fcdc_89934_DS1.pdf\%3F\& usg=AOvVaw1eud3bEOijh9iHTx2nmyxg (accessed on 28 June 2020).

28. Centers for Disease Control and Prevention. Coronavirus Disease 2019 (COVID-19). Frequently Asked Questions. Available online: https:/ / www.cdc.gov/coronavirus/2019-ncov/ faq.html (accessed on 12 February 2020).

29. Chilimuri, S.; Sun, H.; Alemam, A.; Manthri, N.; Shehi, E.; Tejada, J.; Yugay, A.; Nayudu, S.K. Predictors of Mortality in Adults Admitted with COVID-19: Retrospective Cohort Study from New York City. West. J. Emerg. Med. 2020, 21, 779-784. [CrossRef]

30. Christianson, S.; Goodman, J.; Loftus, E.F. Eyewitness memory for stressful events: Methodological quandaries and ethical dilemmas. In The Handbook of Emotion and Memory: Research and Theory; Psychology Press: London, UK, $1992 ;$ pp. $217-241$.

31. Chua, A.Y.; Banerjee, S. To share or not to share: The role of epistemic belief in online health rumors. Int. J. Med. Inform. 2017, 108, 36-41. [CrossRef]

32. Chua, A.Y.; Banerjee, S. Intentions to trust and share online health rumors: An experiment with medical profes-sionals. Comput. Hum. Behav. 2018, 87, 1-9. [CrossRef]

33. Chyung, S.Y.; Winiecki, D.; Hunt, G.; Sevier, C.M. Measuring Learners' Attitudes Toward Team Projects: Scale Development Through Exploratory and Confirmatory Factor Analyses. Am. J. Eng. Educ. AJEE 2017, 8, 61-82. [CrossRef]

34. Cinelli, M.; Quattrociocchi, W.; Galeazzi, A.; Valensise, C.M.; Brugnoli, E.; Schmidt, A.L.; Zola, P.; Zollo, F.; Scala, A. The COVID-19 social media infodemic. Sci. Rep. 2020, 10, 1-10. [CrossRef]

35. Clark, L.A.; Watson, D. Constructing validity: Basic issues in objective scale development. Psychol. Assess. 1995, 7, 309-319. [CrossRef]

36. Cohen, S. Folk Devils and Moral Panics: The Creation of the Mods and Rockers; Taylor \& Francis: Abingdon, UK, 1972.

37. Colins, O.F.; Andershed, H.; Hawes, S.W.; Bijttebier, P.; Pardini, D.A. Psychometric Properties of the Original and Short Form of the Inventory of Callous-Unemotional Traits in Detained Female Adolescents. Child. Psychiatry Hum. Dev. 2015, 47, 679-690. [CrossRef] [PubMed]

38. Dbouk, T.; Drikakis, D. On respiratory droplets and face masks. Phys. Fluids 2020, 32, 063303. [CrossRef] 
39. Ellis, B.; Degh, L. Legend and Belief: Dialectics of a Folklore Genre. West. Folk. 2001, 60, 227. [CrossRef]

40. Dégh, L.; Vázsonyi, A. Does the word “Dog” bite? Ostensive action: A means of legend-telling. J. Folk. Res. 1983, $20,5-34$.

41. Desjardins, M.; Hohl, A.; Delmelle, E. Rapid surveillance of COVID-19 in the United States using a prospective space-time scan statistic: Detecting and evaluating emerging clusters. Appl. Geogr. 2020, 118, 102202. [CrossRef]

42. DiFonzo, N.; Bourgeois, M.J.; Suls, J.; Homan, C.; Stupak, N.; Brooks, B.P.; Ross, D.S.; Bordia, P. Rumor clustering, consensus, and polarization: Dynamic social impact and self-organization of hearsay. J. Exp. Soc. Psychol. 2013, 49, 378-399. [CrossRef]

43. Donnellan, M.B.; Oswald, F.L.; Baird, B.M.; Lucas, R. The Mini-IPIP Scales: Tiny-yet-effective measures of the Big Five Factors of Personality. Psychol. Assess. 2006, 18, 192-203. [CrossRef]

44. Donovan, P. How Idle is Idle Talk? One Hundred Years of Rumor Research. Diogenes 2007, 54, 59-82. [CrossRef]

45. Duncan, L.A.; Schaller, M.; Park, J.H. Perceived vulnerability to disease: Development and validation of a 15-item self-report instrument. Pers. Individ. Differ. 2009, 47, 541-546. [CrossRef]

46. Dunn, S.C.; Seaker, R.F.; Waller, M.A. Latent variables in business logistics research: Scale development and val-idation. J. Bus. Logist. 1994, 15, 145-172.

47. Dutta, S.; Acharya, S.; Shukla, S.; Acharya, N. COVID-19 Pandemic-revisiting the myths. SSRG Int. J. Med. Sci. 2020, 7, 7-10. [CrossRef]

48. Ellis, B. "Fake news" in the contemporary legend dynamic. J. Am. Folk. 2018, 131, 398-404. [CrossRef]

49. Faasse, K.; Newby, J. Public Perceptions of COVID-19 in Australia: Perceived Risk, Knowledge, Health-Protective Behaviors, and Vaccine Intentions. Front. Psychol. 2020, 11, 551004. [CrossRef]

50. Feng, S.; Shen, C.; Xia, N.; Song, W.; Fan, M.; Cowling, B.J. Rational use of face masks in the COVID-19 pandemic. Lancet Respir. Med. 2020, 8, 434-436. [CrossRef]

51. Fine, G.A. Rumor, Trust and Civil Society: Collective Memory and Cultures of Judgment. Diogenes 2007, 54, 5-18. [CrossRef]

52. Fine, G.A.; Heath, C. Rumor Mills: The Social Impact of Rumor and Legend; Transaction Publishers: Piscataway, NJ, USA, 2009.

53. Gibbons, R.D.; Clark, D.C.; Cavanaugh, S.V.; Davis, J.M. Application of modern psychometric theory in psychiatric research. J. Psychiatr. Res. 1985, 19, 43-55. [CrossRef]

54. Goldberg, L.R. The development of markers for the Big-Five factor structure. Psychol. Assess. 1992, 4, 26-42. [CrossRef]

55. Fine, G.A.; Goldstein, D.E. Once upon a Virus: AIDS Legends and Vernacular Risk Perception. J. Am. Folk. 2009, 122, 102. [CrossRef]

56. Golmaryami, F.N.; Vaughan, E.P.; Frick, P.J. Callous-unemotional traits and romantic relationships. Pers. Individ. Differ. 2020, 168, 110408. [CrossRef]

57. Goode, E.; Ben-Yehuda, N. Moral Panics: The Social Construction of Deviance; Wiley Online Library: Hoboken, NJ, USA, 2010.

58. Grubaugh, N.D.; Hanage, W.P.; Rasmussen, A.L. Making Sense of Mutation: What D614G Means for the COVID-19 Pandemic Remains Unclear. Cell 2020, 182, 794-795. [CrossRef]

59. Gruzd, A.; Mai, P. Going viral: How a single tweet spawned a COVID-19 conspiracy theory on Twitter. Big Data Soc. 2020, 7, 2053951720938405. [CrossRef]

60. Hair, J.F., Jr.; Black William, C.; Babin Barry, J.; Anderson Rolph, E. Multivariate Data Analysis, 7th ed.; Prentice Hall: Upper Saddle River, NJ, USA, 2010.

61. Haischer, M.H.; Beilfuss, R.; Hart, M.R.; Opielinski, L.; Wrucke, D.; Zirgaitis, G.; Uhrich, T.D.; Hunter, S.K. Who is wearing a mask? Gender-, age-, and location-related differences during the COVID-19 pandemic. PLoS ONE 2020, 15, e0240785. [CrossRef] [PubMed]

62. Hayes, A.F. PROCESS: A Versatile Computational Tool for Observed Variable Mediation, Moderation, and Conditional Process Modeling. 2012. Available online: http:/ / www.afhayes.com/public/process2012.pdf (accessed on 8 August 2020).

63. Hayes, A.F. An Index and Test of Linear Moderated Mediation. Multivar. Behav. Res. 2015, 50, 1-22. [CrossRef] [PubMed]

64. Hayes, A.F. Introduction to Mediation, Moderation, and Conditional Process Analysis: A Regression-Based Approach; Guilford Publications: New York, NY, USA, 2017.

65. Hayes, A. Partial, conditional, and moderated moderated mediation: Quantification, inference, and interpretation. Commun Monogr. 2017, 85, 4-40. [CrossRef]

66. Heaven, P.C.L.; Bucci, S. Right-wing authoritarianism, social dominance orientation and personality: An analysis using the IPIP measure. Eur. J. Pers. 2001, 15, 49-56. [CrossRef]

67. Heller, J. Rumors and Realities: Making Sense of HIV/AIDS Conspiracy Narratives and Contemporary Legends. Am. J. Public Health 2015, 105, e43-e50. [CrossRef]

68. Highhouse, S.; Bottrill, K.V. The Influence of Social (Mis)Information on Memory for Behavior in an Employment Interview. Organ. Behav. Hum. Decis. Process. 1995, 62, 220-229. [CrossRef]

69. Hilbert, M. Toward a synthesis of cognitive biases: How noisy information processing can bias human decision making. Psychol. Bull. 2012, 138, 211-237. [CrossRef] [PubMed]

70. Hill, T.D.; Gonzalez, K.; Burdette, A.M. The Blood of Christ Compels Them: State Religiosity and State Population Mobility During the Coronavirus (COVID-19) Pandemic. J. Relig. Health 2020, 59, 2229-2242. [CrossRef] [PubMed]

71. Hinkin, T.R. A review of scale development practices in the study of organizations. J. Manag. 1995, 21, 967-988. [CrossRef]

72. Hinkin, T.R. Scale development principles and practices. In Research in Organizations: Foundations and Methods of Inquiry; Berrett Koehler: Oakland, CA, USA, 2005; pp. 161-179. 
73. Hulland, J. Use of partial least squares (PLS) in strategic management research: A review of four recent studies. Strateg. Manag. J. 1999, 20, 195-204. [CrossRef]

74. Huynh, T.D. The more I fear about COVID-19, the more I wear medical masks: A survey on risk perception and medical masks uses. MedRxiv 2020. [CrossRef]

75. Jaja, I.F.; Anyanwu, M.U.; Jaja, C.-J.I. Social distancing: How religion, culture and burial ceremony undermine the effort to curb COVID-19 in South Africa. Emerg. Microbes Infect. 2020, 9, 1077-1079. [CrossRef] [PubMed]

76. Jamieson, K.H.; Albarracin, D. The Relation between Media Consumption and Misinformation at the Outset of the SARS-CoV-2 Pandemic in the US; The Harvard Kennedy School Misinformation Review: $2020 . \quad$ Available online: https: / / misinforeview.hks.harvard.edu/article/the-relation-between-media-consumption-and-misinformation-at-the-outsetof-the-SARS-CoV-2-pandemic-in-the-us / (accessed on 24 August 2021).

77. Jöbges, S.; Vinay, R.; Luyckx, V.A.; Biller-Andorno, N. Recommendations on COVID-19 triage: International comparison and ethical analysis. Bioethics 2020, 34, 948-959. [CrossRef]

78. Johansson, M.A.; Quandelacy, T.M.; Kada, S.; Prasad, P.V.; Steele, M.; Brooks, J.T.; Slayton, R.B.; Biggerstaff, M.; Butler, J.C. SARS-CoV-2 Transmission from People Without COVID-19 Symptoms. JAMA Netw. Open 2021, 4, e2035057. [CrossRef]

79. Johnson, J.A. Measuring thirty facets of the Five Factor Model with a 120-item public domain inventory: Development of the IPIP-NEO-120. J. Res. Pers. 2014, 51, 78-89. [CrossRef]

80. Kavish, N.; Sellbom, M.; Anderson, J.L. Implications for the Measurement of Psychopathy in the DSM-5 Using the Computerized Adaptive Test of Personality Disorder. J. Pers. Assess. 2018, 101, 468-480. [CrossRef] [PubMed]

81. Keith, M.G.; Tay, L.; Harms, P.D. Systems perspective of Amazon Mechanical Turk for organizational research: Review and recommendations. Front. Psychol. 2017, 8, 1359. [CrossRef]

82. Khalid, Z.; Yousaf, M.A.; Khan, A.T.-A.; Shakoori, F.R.; Munir, M.; Shakoori, A.R. Debunking Myths about COVID-19, Paranoiac Misconceptions, Recent Developments and its Current Stance. Pak. J. Zool. 2020, 52, 2377. [CrossRef]

83. Kim, H.-Y. Statistical notes for clinical researchers: Assessing normal distribution (2) using skewness and kurtosis. Restor. Dent. Endod. 2013, 38, 52-54. [CrossRef]

84. Kitta, A. Alternative Health Websites and Fake News: Taking a Stab at Definition, Genre, and Belief. J. Am. Folk. 2018, 131, 405-412. [CrossRef]

85. Kitta, A. The Kiss of Death: Contagion, Contamination, and Folklore; University Press of Colorado: Boulder, CO, USA, 2019. [CrossRef]

86. Kitta, A.; Goldberg, D.S. The significance of folklore for vaccine policy: Discarding the deficit model. Crit. Public Health 2016, 27, 506-514. [CrossRef]

87. Kline, R.B. Response to Leslie Hayduk's Review of Principles and Practice of Structural Equation Modeling, 4th Edition. Can. Stud. Popul. 2018, 45, 188-195. [CrossRef]

88. Klompas, M. Coronavirus Disease 2019 (COVID-19): Protecting Hospitals from the Invisible. Ann. Intern. Med. 2020, 172, 619-620. [CrossRef] [PubMed]

89. Kwon, M.; Kim, D.-J.; Cho, H.; Yang, S. The Smartphone Addiction Scale: Development and Validation of a Short Version for Adolescents. PLoS ONE 2013, 8, e83558. [CrossRef]

90. Lasisi, T.T.; Eluwole, K.K. Is the weather-induced COVID-19 spread hypothesis a myth or reality? Evidence from the Russian Federation. Environ. Sci. Pollut. Res. 2020, 28, 4840-4844. [CrossRef] [PubMed]

91. Lelieveld, J.; Helleis, F.; Borrmann, S.; Cheng, Y.; Drewnick, F.; Haug, G.; Klimach, T.; Sciare, J.; Su, H.; Pöschl, U. Model Calculations of Aerosol Transmission and Infection Risk of COVID-19 in Indoor Environments. Int. J. Environ. Res. Public Health 2020, 17, 8114. [CrossRef]

92. Li, T.; Liu, Y.; Li, M.; Qian, X.; Dai, S.Y. Mask or no mask for COVID-19: A public health and market study. PLoS ONE 2020, 15, e0237691. [CrossRef]

93. Lobato, E.J.; Powell, M.; Padilla, L.M.; Holbrook, C. Factors predicting willingness to share COVID-19 misinfor-mation. Front. Psychol. 2020, 11, 2413. [CrossRef]

94. Loftus, E.F. Leading questions and the eyewitness report. Cogn. Psychol. 1975, 7, 560-572. [CrossRef]

95. Lucas, R.E.; Diener, E.; Suh, E. Discriminant validity of well-being measures. J. Personal. Soc. Psychol. 1996, 71, 616. [CrossRef]

96. MacCallum, R.C.; Browne, M.W.; Sugawara, H.M. Power analysis and determination of sample size for covariance structure modeling. Psychol. Methods 1996, 1, 130. [CrossRef]

97. Mahale, P.; Rothfuss, C.; Bly, S.; Kelley, M.; Bennett, S.; Huston, S.L.; Robinson, S. Multiple COVID-19 outbreaks linked to a wedding reception in rural Maine-7 August-14 September 2020. Morb. Mortal. Wkly. Rep. 2020, 69, 1686. [CrossRef]

98. Majra, D.; Benson, J.; Pitts, J.; Stebbing, J. SARS-CoV-2 (COVID-19) superspreader events. J. Infect. 2020, 82, 36-40. [CrossRef]

99. Maloney, P.W.; Grawitch, M.; Barber, L. The multi-factor structure of the Brief Self-Control Scale: Discriminant validity of restraint and impulsivity. J. Res. Pers. 2012, 46, 111-115. [CrossRef]

100. Marsh, A.A.; Finger, E.; Mitchell, D.G.V.; Reid, M.E.; Sims, C.; Kosson, D.S.; Towbin, K.E.; Leibenluft, E.; Pine, D.S.; Blair, R.J.R. Reduced Amygdala Response to Fearful Expressions in Children and Adolescents with Callous-Unemotional Traits and Disruptive Behavior Disorders. Am. J. Psychiatry 2008, 165, 712-720. [CrossRef] [PubMed]

101. Mathieu, J.E.; Farr, J.L. Further evidence for the discriminant validity of measures of organizational commitment, job involvement, and job satisfaction. J. Appl. Psychol. 1991, 76, 127. [CrossRef] 
102. Maves, R.C.; Downar, J.; Dichter, J.R.; Hick, J.L.; Devereaux, A.; Geiling, J.A.; Kissoon, N.; Hupert, N.; Niven, A.S.; King, M.A. Triage of scarce critical care resources in COVID-19: An implementation guide for regional allocation an expert panel report of the Task Force for Mass Critical Care and the American College of Chest Physicians. Chest 2020, 158, 212-225. [CrossRef]

103. Mazzoni, G.; Vannucci, M. Hindsight Bias, the Misinformation Effect, and False Autobiographical Memories. Soc. Cogn. 2007, 25, 203-220. [CrossRef]

104. Papakyriakopoulos, O.; Serrano, J.C.M.; Hegelich, S. The Spread of COVID-19 Conspiracy Theories on Social Media and the Effect of Content Moderation. Harvard Kennedy School Misinformation Review, 2020; p. 1. [CrossRef]

105. Paul, S.K.; Chowdhury, P. Strategies for Managing the Impacts of Disruptions During COVID-19: An Example of Toilet Paper. Glob. J. Flex. Syst. Manag. 2020, 21, 283-293. [CrossRef]

106. Pechorro, P.; Hawes, S.W.; Gonçalves, R.A.; Ray, J.V. Psychometric properties of the inventory of callous-unemotional traits short version (ICU-12) among detained female juvenile offenders and community youths. Psychol. Crime Law 2017, 23, 221-239. [CrossRef]

107. Petersen, M.B.; Osmundsen, M.; Arceneaux, K. The "need for chaos" and motivations to share hostile political rumors. PsyArXiv 2020. [CrossRef]

108. Peterson, R.A. A Meta-Analysis of Variance Accounted for and Factor Loadings in Exploratory Factor Analysis. Mark. Lett. 2000, 11, 261-275. [CrossRef]

109. Porzio, G.; Cortellini, A.; Bruera, E.; Verna, L.; Ravoni, G.; Peris, F.; Spinelli, G. Home Care for Cancer Patients During COVID-19 Pandemic: The Double Triage Protocol. J. Pain Symptom Manag. 2020, 60, e5-e7. [CrossRef]

110. Preacher, K.J.; Rucker, D.D.; Hayes, A. Addressing Moderated Mediation Hypotheses: Theory, Methods, and Prescriptions. Multivar. Behav. Res. 2007, 42, 185-227. [CrossRef]

111. QC, I.F. COVID-19: Fear, quackery, false representations and the law. Int. J. Law Psychiatry 2020, $72,101611$.

112. Ranney, M.L.; Griffeth, V.; Jha, A.K. Critical Supply Shortages-The Need for Ventilators and Personal Protective Equipment during the COVID-19 Pandemic. N. Engl. J. Med. 2020, 382, e41. [CrossRef]

113. Rasmussen, S.; Sperling, P.; Poulsen, M.S.; Emmersen, J.; Andersen, S. Medical students for health-care staff shortages during the COVID-19 pandemic. Lancet 2020, 395, e79-e80. [CrossRef]

114. Raykov, T.; Marcoulides, G.A. Introduction to Psychometric Theory; Routlegde: London, UK, 2011. [CrossRef]

115. Raymond, J.R. The Great Mask Debate: A Debate That Shouldn't Be a Debate at All. WMJ 2020, 119, 229-239. [PubMed]

116. Rieger, M.O. To wear or not to wear? Factors influencing wearing face masks in Germany during the COVID-19 pandemic. Soc. Health Behav. 2020, 3, 50. [CrossRef]

117. Robbins, M.; Francis, L.J.; Edwards, B. Happiness as Stable Extraversion: Internal Consistency Reliability and Construct Validity of the Oxford Happiness Questionnaire Among Undergraduate Students. Curr. Psychol. 2010, 29, 89-94. [CrossRef]

118. Rosnow, R.L. Rumor as Communication: A Contextualist Approach. J. Commun. 1988, 38, 12-28. [CrossRef]

119. Rosnow, R.L. Inside rumor: A personal journey. Am. Psychol. 1991, 46, 484. [CrossRef]

120. Sahoo, S.; Padhy, S.K.; Ipsita, J.; Mehra, A.; Grover, S. Demystifying the myths about COVID-19 infection and its societal importance. Asian J. Psychiatry 2020, 54, 102244. [CrossRef]

121. Samore, T.; Fessler, D.M.T.; Sparks, A.M.; Holbrook, C. Of pathogens and party lines: Social conservatism positively associates with COVID-19 precautions among U.S. Democrats but not Republicans. PLoS ONE 2021, 16, e0253326. [CrossRef]

122. Sanfilippo, F.; Bignami, E.; Lorini, L.F.; Astuto, M. The importance of a "socially responsible" approach during COVID-19: The invisible heroes of science in Italy. Crit. Care 2020, 24, 1-2. [CrossRef] [PubMed]

123. Satici, B.; Gocet-Tekin, E.; Deniz, M.E.; Satici, S.A. Adaptation of the Fear of COVID-19 Scale: Its Association with Psychological Distress and Life Satisfaction in Turkey. Int. J. Ment. Health Addict. 2020, 1-9. [CrossRef]

124. Schmidt, F.L.; Le, H.; Ilies, R. Beyond alpha: An empirical examination of the effects of different sources of meas-urement error on reliability estimates for measures of individual-differences constructs. Psychol. Methods 2003, 8, 206-224. [CrossRef]

125. Sell, T.K.; Hosangadi, D.; Trotochaud, M. Misinformation and the US Ebola communication crisis: Analyzing the veracity and content of social media messages related to a fear-inducing infectious disease outbreak. BMC Public Health 2020, 20, 1-10 [CrossRef]

126. Shahsavari, S.; Holur, P.; Wang, T.; Tangherlini, T.R.; Roychowdhury, V. Conspiracy in the time of corona: Auto-matic detection of emerging COVID-19 conspiracy theories in social media and the news. J. Comput. Soc. Sci. 2020, 3, 279-317. [CrossRef]

127. Singh, L.; Bansal, S.; Bode, L.; Budak, C.; Chi, G.; Kawintiranon, K.; Padden, C.; Vanarsdall, R.; Vraga, E.; Wang, Y. A first look at COVID-19 information and misinformation sharing on Twitter. arXiv 2020, arXiv:2003.13907.

128. Sobering, K. Watercooler Democracy: Rumors and Transparency in a Cooperative Workplace. Work. Occup. 2019, 46, 411-440. [CrossRef]

129. Steffens, M.S.; Dunn, A.G.; Wiley, K.E.; Leask, J. How organisations promoting vaccination respond to misinfor-mation on social media: A qualitative investigation. BMC Public Health 2019, 19, 1-12. [CrossRef] [PubMed]

130. Stephens, M. A geospatial infodemic: Mapping Twitter conspiracy theories of COVID-19. Dialogues Hum. Geogr. 2020, 10, $276-281$. [CrossRef]

131. Tabachnick, B.G.; Fidell, L.S.; Ullman, J.B. Using Multivariate Statistics; Pearson: Boston, MA, USA, 2007 ; Volume 5. 
132. Tang, J.W.; Bahnfleth, W.P.; Bluyssen, P.M.; Buonanno, G.; Jimenez, J.L.; Kurnitski, J.; Li, Y.; Miller, S.; Sekhar, C.; Morawska, L. Dismantling myths on the airborne transmission of severe acute respiratory syndrome coronavirus (SARS-CoV-2). J. Hosp. Infect. 2021, 110, 89-96. [CrossRef] [PubMed]

133. Tangherlini, T.R.; Shahsavari, S.; Shahbazi, B.; Ebrahimzadeh, E.; Roychowdhury, V. An automated pipeline for the discovery of conspiracy and conspiracy theory narrative frameworks: Bridgegate, Pizzagate and storytelling on the web. PLoS ONE 2020, 15, e0233879. [CrossRef]

134. Taylor, L. COVID-19 misinformation sparks threats and violence against doctors in Latin America. BMJ 2020, 370, m3088. [CrossRef]

135. Celenay, S.T.; Karaaslan, Y.; Mete, O.; Kaya, D.O. Coronaphobia, musculoskeletal pain, and sleep quality in stay-at home and continued-working persons during the 3-month COVID-19 pandemic lockdown in Turkey. Chronobiol. Int. 2020, 37, 1778-1785. [CrossRef]

136. Truog, R.D.; Mitchell, C.; Daley, G.Q. The Toughest Triage-Allocating Ventilators in a Pandemic. N. Engl. J. Med. 2020, 382, 1973-1975. [CrossRef]

137. Van Der Linden, S.; Roozenbeek, J.; Compton, J. Inoculating Against Fake News About COVID-19. Front. Psychol. 2020, 11, 566790. [CrossRef] [PubMed]

138. Van Mulukom, V.; Pummerer, L.; Alper, S.; Cavojova, V.; Farias, J.E.M.; Kay, C.S.; Lazarevic, L.; Lobato, E.J.C.; Marinthe, G.; Banai, I.P. Antecedents and consequences of COVID-19 conspiracy theories: A rapid review of the evidence. PsyArXiv 2020. [CrossRef]

139. Van Trijp, H.C.; Steenkamp, J.-B.E. Consumers' variety seeking tendency with respect to foods: Measurement and managerial implications. Eur. Rev. Agric. Econ. 1992, 19, 181-195. [CrossRef]

140. Wang, P.-W.; Hsiao, R.C.; Chen, L.M.; Sung, Y.-H.; Hu, H.-F.; Yen, C.-F. Associations between callous-unemotional traits and various types of involvement in school bullying among adolescents in Taiwan. J. Formos. Med. Assoc. 2018, 118, 50-56. [CrossRef]

141. Wang, Y.; McKee, M.; Torbica, A.; Stuckler, D. Systematic literature review on the spread of health-related misin-formation on social media. Soc. Sci. Med. 2019, 240, 1-12. [CrossRef]

142. Watson, D.; Clark, L.A.; Tellegen, A. Development and validation of brief measures of positive and negative affect: The PANAS scales. J. Personal. Soc. Psychol. 1988, 54, 1063-1070. [CrossRef]

143. West, S.G.; Finch, J.F.; Curran, P.J. Structural equation models with nonnormal variables: Problems and remedies. In Structural Equation Modeling: Concepts, Issues, and Applications; Sage Publications: Thousand Oaks, CA, USA, 1995; pp. 56-75.

144. White, D.B.; Lo, B. A Framework for Rationing Ventilators and Critical Care Beds During the COVID-19 Pandemic. JAMA 2020, 323, 1773. [CrossRef] [PubMed]

145. World Health Organization. Coronavirus Disease (COVID-19) Advice for the Public. Mythbusters. Available online: https://www. who.int/emergencies/diseases/novel-coronavirus-2019/advice-for-public/myth-busters (accessed on 23 November 2020).

146. Worthington, R.L.; Whittaker, T.A. Scale development research: A content analysis and recommendations for best practices. Couns. Psychol. 2006, 34, 806-838. [CrossRef]

147. Wright, A.G.C.; Simms, L.J. On the structure of personality disorder traits: Conjoint analyses of the CAT-PD, PID-5, and NEO-PI-3 trait models. Pers. Disord. Theory Res. Treat. 2014, 5, 43-54. [CrossRef] [PubMed]

148. Yang, S.; Jiang, J.; Pal, A.; Yu, K.; Chen, F.; Yu, S. Analysis and Insights for Myths Circulating on Twitter During the COVID-19 Pandemic. IEEE Open J. Comput. Soc. 2020, 1, 209-219. [CrossRef] 